Article

\title{
Synergetic photo-epoxidation of propylene with molecular oxygen over bimetallic $\mathrm{Au}-\mathrm{Ag} / \mathrm{TS}-1$ photocatalysts
}

\author{
Naixu Li a, Bin Yanga a, Ming Liu a, Yong Chen a, Jiancheng Zhou a,b,c,* \\ a School of Chemistry and Chemical Engineering, Southeast University, Nanjing 211189, Jiangsu, China \\ b Department of Chemical and Pharmaceutical Engineering, Southeast University Chengxian College, Nanjing 210088, Jiangsu, China \\ c Jiangsu Province Hi-Tech Key Laboratory for Bio-medical Research, Southeast University, Nanjing 211189, Jiangsu, China
}

\section{A R T I C L E I N F}

\section{Article history:}

Received 2 January 2017

Accepted 1 April 2017

Published 5 May 2017

\section{Keywords:}

Gold

Silver

Titanium silicalite-1

Photocatalysis

Propene epoxidation

Synergetic effect

\begin{abstract}
A B S T R A C T
$\mathrm{Au}-\mathrm{Ag}$ bimetallic nanoparticle-supported microporous titanium silicalite-1 catalysts were prepared via a hydrothermal-immersion method, and their structures were examined. These materials serve as efficient catalysts for the photosynthesis of propylene oxide via the epoxidation of propene. The $\mathrm{Au} / \mathrm{Ag}$ mass ratio and reaction temperature were demonstrated to have significant effects on the catalytic activity and selectivity of propylene oxide. The optimal formation rate $(68.3 \mu \mathrm{mol} / \mathrm{g} \cdot \mathrm{h})$ and selectivity (52.3\%) toward propylene oxide were achieved with an Au:Ag mass ratio of 4:1. Notably, the strong synergistic effect between Au and Ag resulted in superior photocatalysis of the bimetallic systems compared with those of the individual systems. A probable reaction mechanism was proposed based on the theoretical and experimental results.
\end{abstract}

(C) 2017, Dalian Institute of Chemical Physics, Chinese Academy of Sciences. Published by Elsevier B.V. All rights reserved.

\section{Introduction}

Propylene oxide (PO) is an increasingly important bulk chemical for materials containing propylene glycol and polyurethanes, which are used to produce commercial products such as adhesives, paints, and cosmetics [1]. The typical production of PO through chlorohydrin and hydroperoxidation processes is far from economically and environmentally benign [2]. Recently, numerous research activities on PO preparation over $\mathrm{Au}$ species from propylene and molecular oxygen have resulted in a significant advancement in the green and mild fabrication of this compound.

Suo et al. [3] reported $\mathrm{Au}$-supported $\mathrm{SiO}_{2}$ for the green conversion of propylene with dioxygen and dihydrogen to PO at $598 \mathrm{~K}$ and GHSV $=6000 \mathrm{~h}^{-1}$. The catalytic system proved ineffi- cient for the partial oxidation of propylene to PO because of the excessively low propylene conversion $(0.9 \%)$ and selectivity to PO (17.9\%) during the initial $10 \mathrm{~min}$ of the reaction. Jin et al. [4] achieved high selectivity toward PO (60.3\%) on a $20 \% \mathrm{Ag}-4 \% \mathrm{MoO}_{3} / \mathrm{ZrO}_{2}$ catalyst at $673 \mathrm{~K}, 0.1 \mathrm{MPa}$, and GHSV = $7500 \mathrm{~h}^{-1}$. However, the extra energy loss in the reaction, low hydrogen efficiency, and safety concern that required $\mathrm{H}_{2} \mathrm{O}_{2}$ production facilities to be limited in size rendered these approaches only temporary solutions. As a promising alternative, the direct photocatalytic gas-phase epoxidation of propylene using oxygen, similar to the direct vapor-phase epoxidation of ethylene over $\mathrm{Ag} / \alpha-\mathrm{Al}_{2} \mathrm{O}_{3}$ catalysts, has gained preference among scholars. Recently, substantial efforts have been devoted to the engineering and tailoring of silica-supported metal oxides such as $\mathrm{V}_{2} \mathrm{O}_{5} / \mathrm{SiO}_{2}$ [5], $\mathrm{Nb}_{2} \mathrm{O}_{5} / \mathrm{SiO}_{2}$ [6], $\mathrm{TiO}_{2} / \mathrm{SiO}_{2}$ [7],

\footnotetext{
* Corresponding author. Tel: +86-25-52090621; Fax: +86-25-52090620; E-mail: jczhou@seu.edu.cn This work was supported by the National Natural Science Foundation of China (21576050) and the Natural Science Foundation of Jiangsu Province (BK20150604).

DOI: 10.1016/S1872-2067(17)62832-8 | http://www.sciencedirect.com/science/journal/18722067 | Chin. J. Catal., Vol. 38, No. 5, May 2017
} 
$\mathrm{ZnO} / \mathrm{SiO}_{2}$ [8], $\mathrm{MgO} / \mathrm{SiO}_{2}$ [9], and $\mathrm{CuO}_{x} / \mathrm{SiO}_{2}$ [10] to promote the photo-epoxidation of propylene in the presence of molecular oxygen. However, studies on Ti-based materials including titanium silicalite- 1 , TS-2, TS- $\beta$, Ti-MCM-41, and Ti-MCM-48 [11-20] for $\mathrm{Au}$ chemical immobilization have demonstrated that tetrahedrally coordinated $\mathrm{Ti}$ is favorable for the enhanced activity and stability of Au species compared with the aforementioned materials. Both enhanced selectivity toward epoxides and stability toward $\mathrm{C}_{3} \mathrm{H}_{6}$ conversion are accessible via $\mathrm{Au}$ incorporation. Therefore, the catalytic materials have triggered interest among scholars searching for superior materials for the highly selective synthesis of $\mathrm{PO}$ via vapor-phase $\mathrm{C}_{3} \mathrm{H}_{6}$ epoxidation.

The catalytic performance of Au-based materials is strongly dependent on the particle size; only particles with sizes below $5 \mathrm{~nm}$ exhibit high reactivity [21-23]. However, Au particles are vulnerable to aggregation upon thermal treatment, leading to a dramatic loss of activity. It is assumed that the addition of a second metal would overcome the aggregation of the monometal $[24,25]$ and would assist in the activation of oxygen $[26,27]$. The physical and chemical properties of bimetallic catalysts greatly vary depending on the composition and particle size, and these catalysts show complementary advantages and synergistic effects. Au-containing bimetallic catalysts such as $\mathrm{Au}-\mathrm{Cu}$ [25,28], $\mathrm{Au}-\mathrm{Ag}$ [29-34], $\mathrm{Au}-\mathrm{Pd}$ [35], and $\mathrm{Au}-\mathrm{Pt}$ [36] can exhibit great catalytic performance in many reactions. Among them, Ag has highly analogous cell parameters, exhibits high affinity for $\mathrm{Au}$ atoms, and easily forms homogeneous bimetallic Au-Ag alloys. Synergistic effects and improved activity have been achieved when using $\mathrm{Au}-\mathrm{Ag}$ bimetals for low-temperature CO oxidation [32,36]. Recently, Wittstock et al. $[37,38]$ claimed that a nanoporous Au catalyst that was dealloyed by $\mathrm{Au}-\mathrm{Ag}$ alloys exhibited high efficiency for oxidative coupling of methanol, and they confirmed that the remaining Ag could tune the availability of active oxygen and facilitate the catalytic activity.

In this study, we prepared a series of $\mathrm{Au}-\mathrm{Ag}$ bimetallic nanoparticles deposited on microporous TS- 1 to investigate the effect of temperature and the bimetallic composition on the catalytic activity. First, TS-1 was hydrothermally treated at 433 $\mathrm{K}$ for $18 \mathrm{~h}$. Second, noble-metal-decorated TS-1 samples were obtained via TS-1 impregnation in precursor solutions. Subsequently, the structure and component-related information were determined using nitrogen adsorption, X-ray diffraction (XRD), Fourier-transform infrared (FTIR) spectroscopy, X-ray photoelectron spectroscopy (XPS), energy-dispersive X-ray spectroscopy (EDX), ultraviolet-visible (UV-vis) spectroscopy, photoluminescence (PL), scanning electron microscopy (SEM), and transmission electron microscopy (TEM) analyses. A comparative analysis of performance tests for an array of $\mathrm{C}_{3} \mathrm{H}_{6}$ photo-epoxidation disclosed the unique synergistic effect of these $\mathrm{Au}-\mathrm{Ag}$ bimetallic catalysts. Finally, a possible reaction mechanism was proposed based on the theoretical and experimental findings.

\section{Experimental}

\subsection{Preparation of photocatalysts}

The TS- 1 support was synthesized according to the procedure presented in Ref. [39]. Typically, $2 \mathrm{~g}$ of polyoxyethylene sorbitan monolaurate (Tween 20; s.d. KESHI) was dissolved in $32 \mathrm{~g}$ of distilled water (resistivity $=18.2 \mathrm{M} \Omega \mathrm{cm}$ ). This solution was added to a tetrapropylammonium hydroxide (TPAOH; $25 \%$ in water) solution. To the above micellar solution, $36 \mathrm{~g}$ of tetraethyl orthosilicate (TEOS; Aldrich) was introduced in a dropwise manner under vigorous stirring. The stirring was continued for $1 \mathrm{~h}$. Next, a mixture of $1.808 \mathrm{~g}$ of tetra- $n$-butyl titanate (TNBT; Aldrich) and $9.12 \mathrm{~g}$ of isopropyl alcohol (IPA; s.d. SCR) was added to the above solution under intense agitation for $1 \mathrm{~h}$. The gel solution was transferred to an autoclave and heated to $433 \mathrm{~K}$ for $18 \mathrm{~h}$ under autogenous pressure. The product was recovered by centrifugation, washed with distilled water, and dried $(383 \mathrm{~K}, 12 \mathrm{~h})$. The starting feedstock had the following molar composition: $0.03 \mathrm{TiO}_{2}: \mathrm{SiO}_{2}$ : $0.12 \mathrm{TPAOH}$ : 0.009Tween 20:0.88IPA: $14.45 \mathrm{H}_{2} \mathrm{O}$. The calcination was performed in a flow of air at $823 \mathrm{~K}$ for $6 \mathrm{~h}$.

The Au-Ag bimetallic nanoparticles supported on microporous TS-1 (denoted $\mathrm{Au}-\mathrm{Ag} / \mathrm{TS}-1$ ) were prepared via an immersion method [40]. TS-1 (0.4 g) was suspended in water (20 mL) containing the required amount of $4.168 \mathrm{mg} / \mathrm{mL}$ $\mathrm{HAuCl} 4 \cdot 3 \mathrm{H}_{2} \mathrm{O}$ (purity $99.999 \%$ metal basis) and $1.25 \mathrm{mg} / \mathrm{mL}$ $\mathrm{AgNO}_{3}(99.8 \%)$. The mixture was sonicated for $2 \mathrm{~h}$ and aged at room temperature for $24 \mathrm{~h}$ in the dark. Then, the solution was dried in a water bath at $353 \mathrm{~K}$, calcined at $573 \mathrm{~K}$ for $4 \mathrm{~h}$ in air, and subsequently reduced in $\mathrm{H}_{2}(99.999 \%)$ at $673 \mathrm{~K}$ for $10 \mathrm{~h}$ to produce the final catalyst labeled $x \mathrm{Au}-y \mathrm{Ag} / \mathrm{TS}-1$ ( $x$ and $y$ define the weight percentage loading of $\mathrm{Au}$ and Ag, respectively). TS-1 samples modified with various mass ratios of $\mathrm{Au}$ to $\mathrm{Ag}$ were prepared using the above protocol.

\subsection{Characterization of photocatalysts}

The $\mathrm{N}_{2}$ sorption isotherm was measured at $77 \mathrm{~K}$ using a Quantachrome NovaWin analyzer. The samples were degassed at $573 \mathrm{~K}$ for $3 \mathrm{~h}$ before the measurements. The specific surface area was calculated using the Brunauer-Emmett-Teller (BET) method. The average pore diameter was determined using the Barrett-Joyner-Halenda method according to the desorption isotherm branch. The total pore volume was dependent on the absorbed $\mathrm{N}_{2}$ volume at a relative pressure of approximately 0.98. Powder XRD patterns were obtained using a SmartLab 3 equipped with a graphite monochromator and $\mathrm{Cu} K_{\beta}$ radiation ( $40 \mathrm{kV}$ and $30 \mathrm{~mA}$ ). The diffraction lines were identified by matching them with reference patterns in the JCPDS database.

TEM and EDX measurements were obtained in scanning TEM (STEM) mode using an H-600-4 electron microscope operated at an acceleration voltage of $200 \mathrm{kV}$. The catalyst powders were lightly ground and ultrasonically dispersed in ethanol at room temperature. The as-obtained solution was then dropped onto copper grids supported by holey carbon films.

XPS analysis was performed using an AXIS-Ultra-instrument (Kratos Analytical) equipped with an $\mathrm{Al} K_{\alpha} \mathrm{X}$-ray radiation source $(\mathrm{h} v=1486.71 \mathrm{eV})$. A flood gun with variable electron 
voltage (from 6-8 eV) was used for charge compensation. The raw data were corrected for substrate charging with the binding energy of the C $1 s$ peak $(284.6 \mathrm{eV})$. The measured spectra were fitted using the least-squares method to a product of Gaussian-Lorentzian functions after removing the background noise. The concentration of each element was calculated from the area of the corresponding peak and calibrated using the Wagner sensitivity factor.

The UV-vis diffuse reflectance spectroscopy of the as-reduced catalysts was performed on a UV-vis-near-infrared spectrophotometer (CARY5000 scan spectrophotometer), and the reduced samples were directly used for the UV-vis measurement. FT-IR spectra were collected on a TENSOR27 PMA 50 FT-IR spectrometer. The analysis of the recombination rate of charges was performed using a F-4600 FL spectrophotometer with an excitation wavelength of $260 \mathrm{~nm}$.

\subsection{Photocatalytic activity}

Fig. 1 shows the apparatus used for the photo-epoxidation of propylene to PO. A total of $0.1 \mathrm{~g}$ of the photocatalysts was fed into a photoreactor, and a 100-W high-pressure mercury lamp $(\lambda=200-600 \mathrm{~nm})$ was used as an irradiation source. The photoreactor was placed in a temperature control box in case heating was required. The reactant gases consisted of a mixture of $\mathrm{C}_{3} \mathrm{H}_{6}$ (99.99\%), $\mathrm{O}_{2}$ (99.999\%), and $\mathrm{Ar}$ (99.999\%) with a volume ratio of 1:1:19. A total gas flow of $21.2 \mathrm{~mL} / \mathrm{min}$ was applied with GHSV $=6000 \mathrm{~h}^{-1}$. The reactants and products were analyzed online and periodically using a gas chromatograph (GC-9850-5V) equipped with a flame ionization detector and a thermal conductivity detector. A PLOT Q column was used to separate the propylene and oxidation products, including $\mathrm{PO}$, propionaldehyde (PA), acrolein (AL), acetone (AC), acetaldehyde (AA), and ethanol (EtOH). However, a carbon molecular sieve (60-80) was used to separate $\mathrm{O}_{2}$ and $\mathrm{CO}_{2}$. The standard definition of conversion was not used in this study. In our study, the conversions were low, in the range of $0.01-1.00 \%$. To accurately quantify the conversions in the photo-epoxidation, we defined the $\mathrm{C}_{3} \mathrm{H}_{6}$ conversion as the sum of all the products converted to $\mathrm{C}_{3}$. The $\mathrm{PO}$ formation rate, $\mathrm{C}_{3} \mathrm{H}_{6}$ conversion rate, and product selectivity were expressed as follows [41]:

PO formation rate $=$ Concentration of the product detected on stream $\times$ flow rate/weight of the photocatalysts (1)

$\mathrm{C}_{3} \mathrm{H}_{6}$ conv. rate $=\sum$ Rate of all products converted to $\mathrm{C}_{3}$ (2)

Product selectivity $=\left(\right.$ Product converted to $\mathrm{C}_{3} /$ all products converted to $\left.C_{3}\right) \times 100 \%$

\section{Results and discussion}

\subsection{Characterization of photocatalysts}

\subsubsection{Physical properties}

Table 1 lists the BET surface areas, average pore sizes, and pore volumes of the catalysts. The BET surface areas (470-528 $\mathrm{m}^{2} / \mathrm{g}$ ) gradually decreased with increasing Ag content in the bimetal loading, indicating that the pores in TS-1 may have been clogged by the metal. However, $\mathrm{Au}-\mathrm{Ag} / \mathrm{TS}-1(4 / 1)$ had a larger specific surface area than TS-1, which suggests that the noble metal was well dispersed on the support and that the channels were not plugged. The bimetallic particle size also showed the same increasing trend (from 2.1 to $4.2 \mathrm{~nm}$ ) with

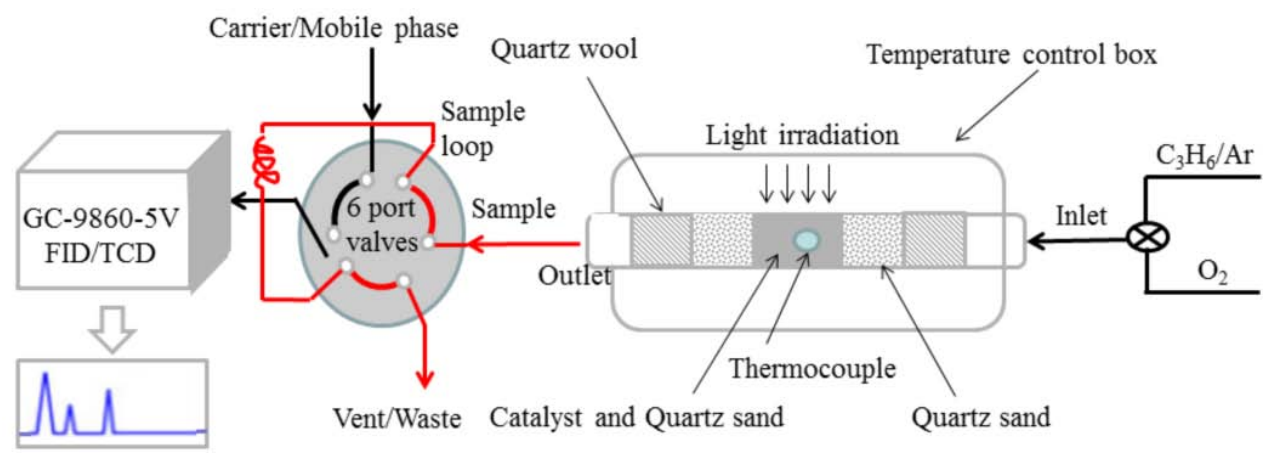

Fig. 1. Apparatus for gas-phase photocatalytic epoxidation of propylene.

Table 1

Chemical composition and textural properties of catalysts and estimated metal particle sizes.

\begin{tabular}{|c|c|c|c|c|c|c|}
\hline No. & Photocatalyst (wt\%) & $\mathrm{Au} /$ Ag mass ratio ${ }^{\mathrm{a}}$ & Pore size $(\mathrm{nm})$ & Pore volume ${ }^{\mathrm{b}}\left(\mathrm{cm}^{3} / \mathrm{g}\right)$ & BET surface area $\left(\mathrm{m}^{2} / \mathrm{g}\right)$ & Metal particle size ${ }^{\mathrm{c}}(\mathrm{nm})$ \\
\hline 1 & TS-1 & - & 1.34 & 0.289 & 519 & - \\
\hline 2 & $0.1 \mathrm{Au} / \mathrm{TS}-1$ & $1: 0$ & 1.20 & 0.267 & 477 & 2.1 \\
\hline 3 & $0.1 \mathrm{Au}-0.025 \mathrm{Ag} / \mathrm{TS}-1$ & $4.15: 1$ & 1.35 & 0.290 & 528 & 2.4 \\
\hline 4 & $0.1 \mathrm{Au}-0.1 \mathrm{Ag} / \mathrm{TS}-1$ & $1.21: 1$ & 1.35 & 0.307 & 472 & 2.9 \\
\hline 5 & $0.1 \mathrm{Au}-0.15 \mathrm{Ag} / \mathrm{TS}-1$ & $2.13: 3.15$ & 1.34 & 0.311 & 470 & 3.2 \\
\hline 6 & $0.15 \mathrm{Ag} / \mathrm{TS}-1$ & $0: 1$ & 1.33 & 0.270 & 463 & 4.2 \\
\hline
\end{tabular}

a $\mathrm{Au} / \mathrm{Ag}$ mass ratio determined by EDX.

b Total pore volume obtained from $p / p_{0}=0.98$.

cParticle size measured by TEM. 
increasing Ag content. In addition, the metal loading did not have a substantial effect on the pore size or volume of TS- 1 . The $\mathrm{Au} / \mathrm{Ag}$ nominal mass ratios were consistent with the compositions measured using EDX.

\subsubsection{XRD analysis}

The structures of the as-prepared catalytic materials were confirmed by XRD. Fig. 2(a) shows diffraction lines at $2 \theta=7.8^{\circ}$, $8.8^{\circ}, 23.2^{\circ}, 23.8^{\circ}$, and $24.5^{\circ}$, representing the indices of the (101), (200), (501), (151), and (313) lattice planes, respectively. The perfect match of these peaks with the standard peaks of the TS-1 curve (JCPDS card no. 70-4276) indicates that the orthorhombic phase and MFI structure of the sample [42-44]. The incorporation of $\mathrm{Ti}^{\mathrm{IV}}$ into the framework is indicated by the change from monoclinic symmetry (S-1) to orthorhombic symmetry (TS-1) by virtue of the disappearance of the peak split at $2 \theta=24.5^{\circ}$ and $29.5^{\circ}$ [44]. In addition, for the $\mathrm{Au}-\mathrm{Ag} / \mathrm{TS}-1$ samples, the perfect coincidence of the shapes and positions of the characteristic peaks with those associated with TS-1 indicates that the metal loading is independent of the latter framework. Nevertheless, diffraction lines attributable to $\mathrm{Au}$ and Ag are hardly observed in Fig. 2(b) because of their exces- sively low loading $(\leq 0.25 \mathrm{wt} \%)$ or high dispersion on the TS-1 surface.

\subsubsection{UV-vis spectra}

The UV-vis spectra in Fig. 3(a) reveal one strong absorption edge at $214 \mathrm{~nm}$. This band is attributed to electronic transitions between $\mathrm{O}^{2-}$ and $\mathrm{Ti}^{4+}$ in the isolated framework $\mathrm{Ti}^{\mathrm{IV}}$ centers in a tetrahedral environment. The absence of an absorption band at 320-400 nm confirms that neither anatase nor extraframework Ti was present in these samples [45]. It is apparent that the absorbance is closely connected with the metal loading. For the monometallic loading, Ag/TS- 1 exhibits high intensity compared with $\mathrm{Au} / \mathrm{TS}-1$, which may be related to its physical and chemical properties. Compared with $\mathrm{Au}, \mathrm{Ag}$ shows a greater tendency to conduct photogenerated charges [46]. For the $\mathrm{Au} / \mathrm{Ag}$ bimetallic catalysts, the absorbance deviated from that of its counterpart with increasing Ag amount. This phenomenon is possibly connected to the bimetallic composition and particle size [21-23]. Similar to the $\mathrm{Au} / \mathrm{Ag}$ (4/1) bimetallic catalyst, the particle size was small and well dispersed on the support, which is favorable for the transfer of photogenerated charges. Therefore, the small addition of $\mathrm{Ag}$ to $\mathrm{Au}$ is beneficial
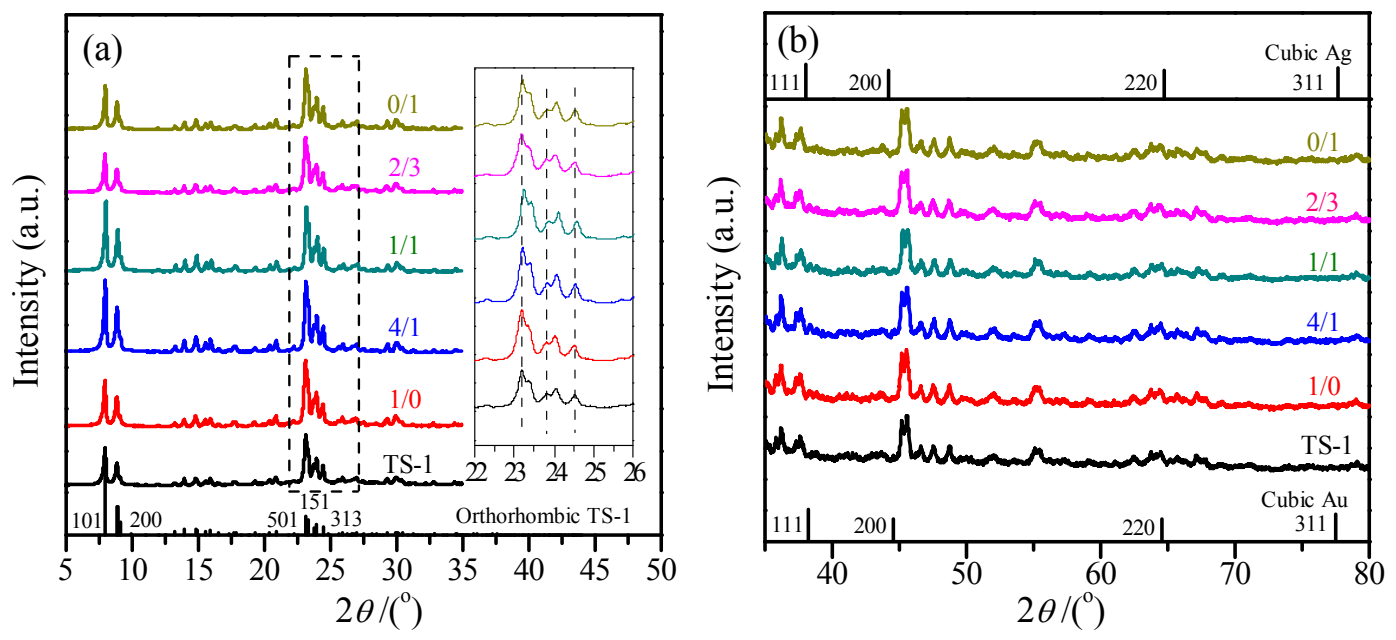

Fig. 2. XRD patterns of catalysts with different $\mathrm{Au} / \mathrm{Ag}$ mass ratios. (a) $2 \theta=5^{\circ}-35^{\circ}$; (b) $2 \theta=35^{\circ}-80^{\circ}$.
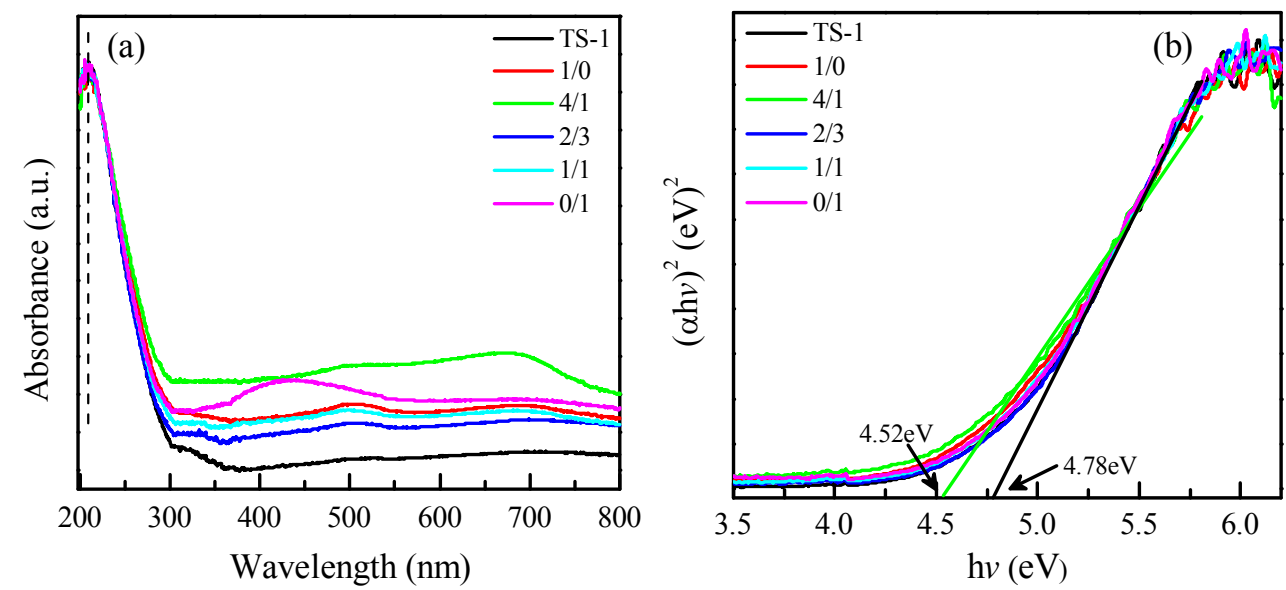

Fig. 3. UV-vis absorption spectra (a) and plot of $(\alpha h v)^{2} v s$. $h v$ (b) for the direct optical band gap of Au-Ag/TS-1 with different Au/Ag mass ratios. 
for the photocatalytic reaction. Our results provide evidence of the close connection between the interfaces at the nanoscale level, leading to the formation of a surface heterojunction, which could affect its electron transfer. The band gap of the catalysts can be calculated using the following empirical formula:

$$
\alpha \mathrm{h} v=\mathrm{A}(\mathrm{h} v-E \mathrm{~g})^{1 / 2}
$$

where $\alpha, v, \mathrm{~h}, E \mathrm{~g}$, and $\mathrm{A}$ are the absorption coefficient, light frequency, Planck constant, bandgap energy, and proportionality constant, respectively. The band gap energies of TS- 1 and $\mathrm{Au}-\mathrm{Ag} / \mathrm{TS}-1$ are shown in the Fig. 3(b). Eg of pure TS-1 was estimated to be $4.78 \mathrm{eV}$, and after the bimetal loading, the absorption edge exhibited a red shift, extending the Eg of $\mathrm{Au}-\mathrm{Ag} / \mathrm{TS}-1(4 / 1)$ to $4.52 \mathrm{eV}$. This result indicates that the absorption intensity of TS-1 in the region of UV light can be increased by bimetal loading, which may be explained by the surface plasmon resonance effect of the metal.

\subsubsection{FTIR spectra}

To further understand the structure of TS-1, FTIR spectra were obtained. The major peaks at $1220,1100,800,550$, and $450 \mathrm{~cm}^{-1}$ are consistent with those of the MFI topology structures. Next, in all cases, the peak centered at $960 \mathrm{~cm}^{-1}$ suggests the incorporation of $\mathrm{Ti}$ into the framework [47-50], as observed in Fig. 4. Moreover, modification of TS-1 with noble metals did not result in variation of the shape or mode of the FTIR curve, implying an untouched structure before and after $\mathrm{Au}$ and Ag loading.

\subsubsection{PL spectra}

PL spectra serve as indicators of the recombination rate of photogenerated excitons, which provides deeper insight into photocatalytic processes. The PL spectra of pure TS- 1 and TS- 1 containing different $\mathrm{Au} / \mathrm{Ag}$ mass ratios contained the same fluorescence peaks with an excited wavelength of $260 \mathrm{~nm}$ (Fig. 5). It is assumed that a photocatalyst will generate electrons and holes under light excitation and that the recombination of electrons and holes will emit fluorescence. A low fluorescence emission intensity indicates a low recombination rate of elec-

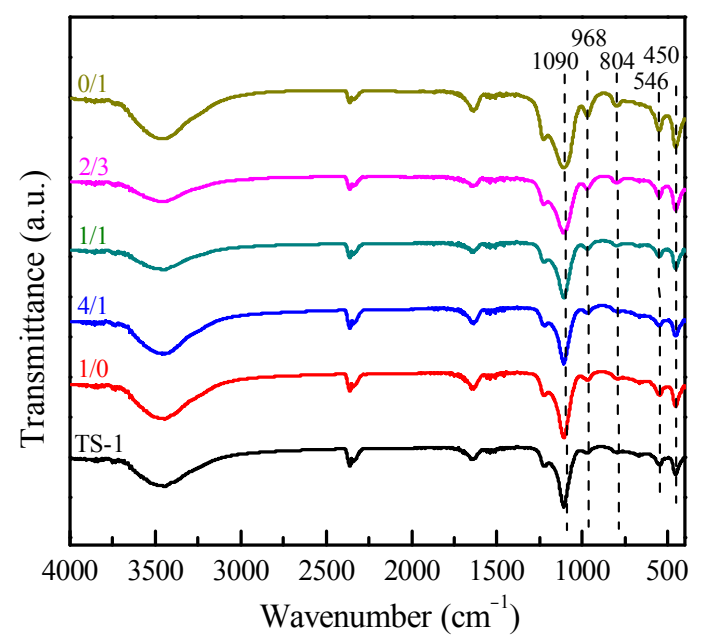

Fig. 4. FTIR spectra of $\mathrm{Au}-\mathrm{Ag} / \mathrm{TS}-1$ with different $\mathrm{Au} / \mathrm{Ag}$ mass ratios.

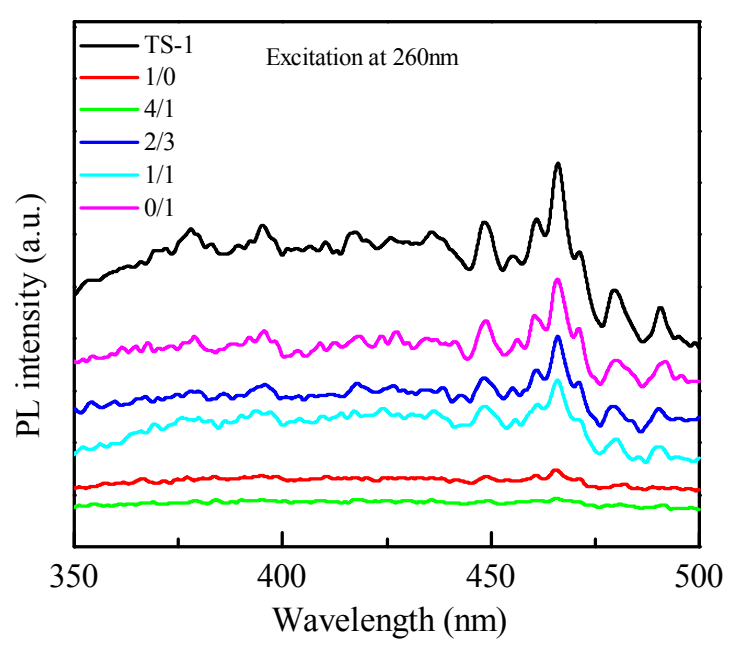

Fig. 5. PL spectra of $\mathrm{Au}-\mathrm{Ag} / \mathrm{TS}-1$ with different $\mathrm{Au} / \mathrm{Ag}$ mass ratios at an excitation wavelength of $260 \mathrm{~nm}$.

trons and holes, which translates into a high photocatalytic activity. In our photocatalytic system, the fluorescence intensity decreased with increasing metal loading, which may be explained by the electron transfer from TS- 1 to the metal and the recombination of photogenerated electrons and holes being inhibited under UV-light irradiation. For monometallic loading, Ag/TS-1 showed high intensity compared with Au/TS-1. However, with increasing $\mathrm{Au}$ content in the $\mathrm{Au} / \mathrm{Ag}$ bimetallic catalysts, the fluorescence intensity gradually decreased, demonstrating that $\mathrm{Au} / \mathrm{Ag}$-loaded on TS-1 provided better ability to deliver electrons and inhibited the recombination of photoinduced charges and holes on the Au/Ag-loaded TS- 1 surface. Among the bimetallic catalysts, $\mathrm{Au} / \mathrm{Ag}$ (4/1) exhibited the lowest intensity, which indicates it demonstrated the best separation effect for the photocatalytic reaction. This phenomenon is consistent with the catalytic activity findings.

\subsubsection{SEM and TEM analyses}

For propylene epoxidation catalyzed by metal nanoparticles, the size of the nanoparticle is an important factor. The particle size and distribution of the $\mathrm{Au}-\mathrm{Ag}$ bimetallic catalysts were determined using SEM and high-resolution TEM. Figs. 6(a) and 7(a) display uniform, isolated, and smooth-surface TS-1 microspheres with a narrow size distribution of $0.4-0.5 \mu \mathrm{m}$. Fig. 6(b) reveals the lattice spacing of $1.003 \mathrm{~nm}$ indexed as the (200) planes of TS- 1 . The metal nanoparticle size is of the first magnitude for elevated catalytic behavior of propene oxidation. High-resolution TEM (HRTEM) images of TS-1 modified with different mass ratios of $\mathrm{Au} / \mathrm{Ag}$ are presented in Fig. 9. The diffraction lines of $\mathrm{Au}-\mathrm{Ag}$ bimetal are similar to those of monometallic nanoparticles because of their similar lattice constants ( 0.408 vs. $0.409 \mathrm{~nm}$ ) and the face-centered-cubic structures of $\mathrm{Au}$ and Ag. Thus, the HRTEM image of $\mathrm{Au}-\mathrm{Ag} / \mathrm{TS}-1(4 / 1)$ in Fig. 6 (c) reveals lattice spacings of $0.236,0.204$, and $0.143 \mathrm{~nm}$ indexed as the (111), (200), and (220) planes of Au-Ag bimetal, respectively. Fig. 6(d) presents an image and EDX pattern of $\mathrm{Au}-\mathrm{Ag} / \mathrm{TS}-1$ (4/1). The sample was a pink powder, with $\mathrm{Ti}, \mathrm{O}$, and Si elements clearly detected in Fig. 6(d). The loadings of $\mathrm{Au}$ and $\mathrm{Ag}$ were small; therefore, $\mathrm{Au}$ and $\mathrm{Ag}$ are not easily detected 

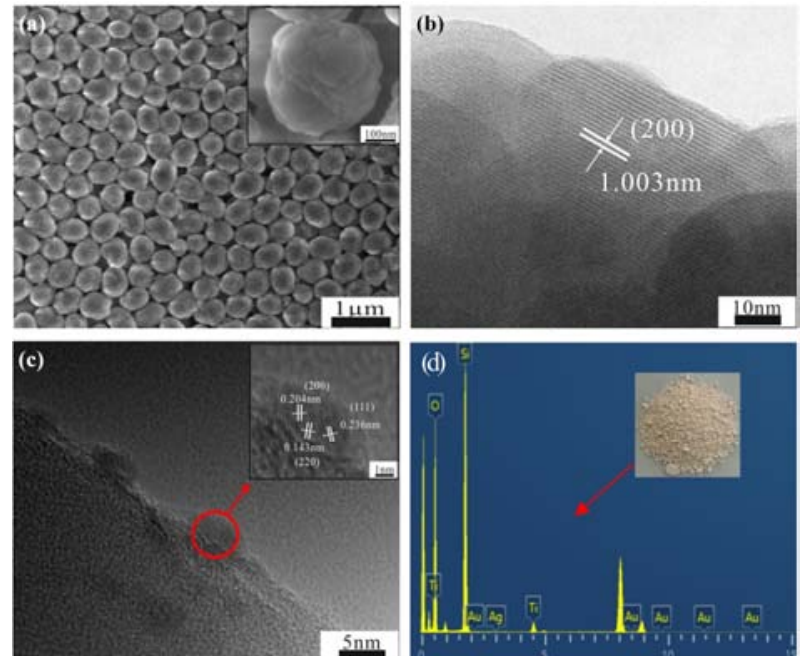

Fig. 6. SEM (a) and HRTEM (b) image of TS-1; HRTEM image (c) and EDX pattern (d) and image (inset) of $\mathrm{Au}-\mathrm{Ag} / \mathrm{TS}-1$ (4/1).

in Fig. 6(d). However, these metals can be clearly observed in the elemental EDX mapping (Fig. 8). The metal particle size and size distribution for the $\mathrm{Au}-\mathrm{Ag}$ bimetallic catalysts are presented in Fig. 7. The particle size of the $\mathrm{Au}-\mathrm{Ag}$ bimetallic catalysts was much larger than that of $\mathrm{Au} / \mathrm{TS}-1$. The samples with $\mathrm{Au} / \mathrm{Ag}$ mass ratios of $4: 1,1: 1,2: 3$, and $0: 1$ had average particle sizes of approximately $2.4,2.9,3.2$, and $4.2 \mathrm{~nm}$, respectively. With increasing Ag content, the particle size increased, which is attributed to the interaction between $\mathrm{Au}$ and $\mathrm{Ag}$. The nanoscale
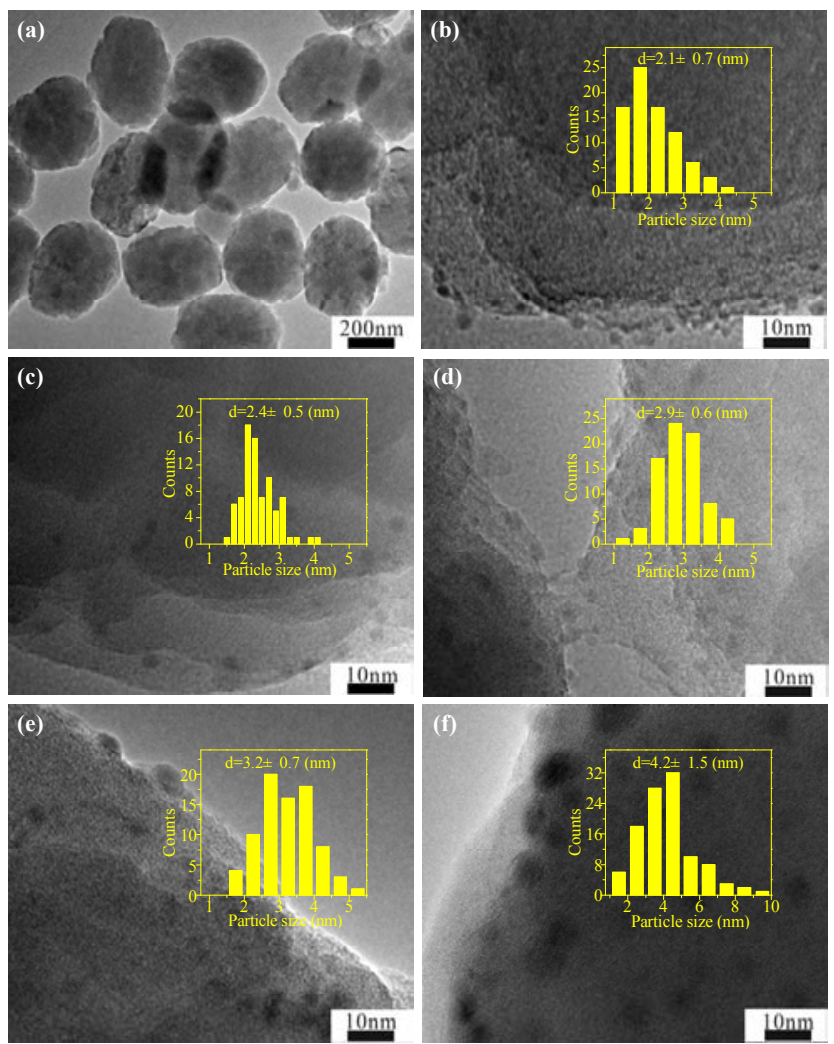

Fig. 7. Particle size and size histograms for TS-1 (a) and $\mathrm{Au} / \mathrm{Ag}$-modified TS-1 for Au/Ag mass ratios of 1/0 (b), $4 / 1$ (c), 1/1 (d), $2 / 3(\mathrm{e})$, and $0 / 1$ (f).
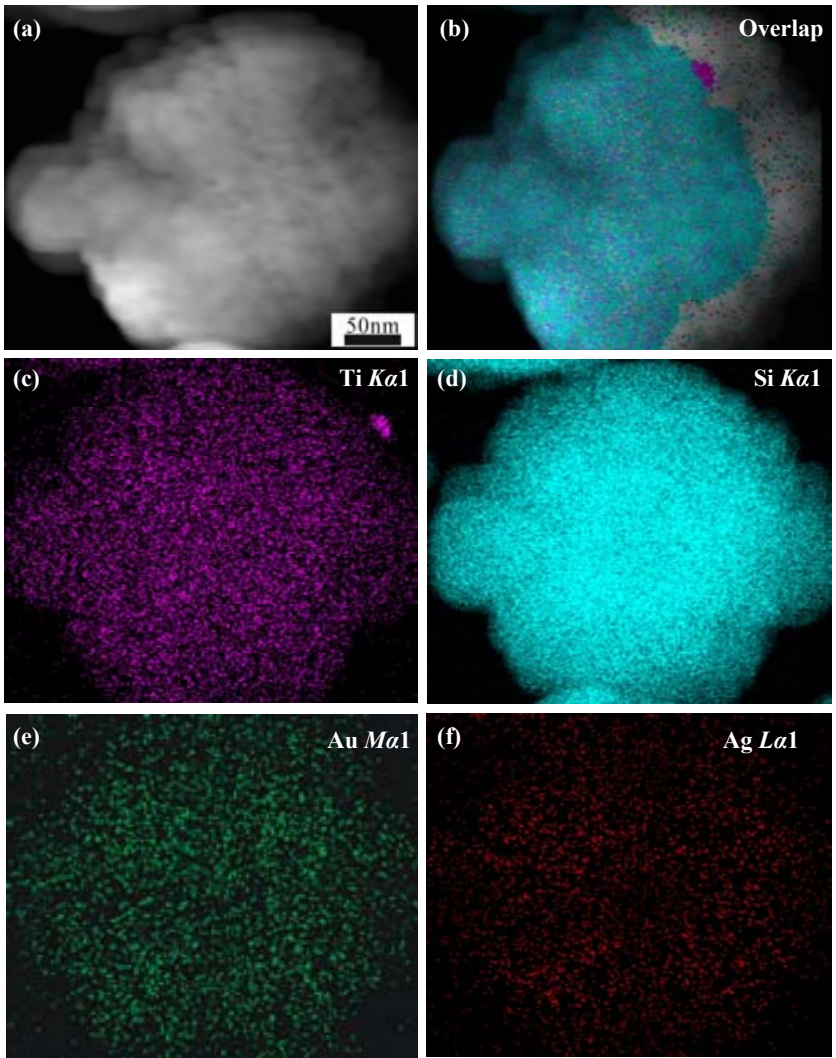

Fig. 8. (a) STEM image of $\mathrm{Au} / \mathrm{Ag}(4 / 1)$ catalyst, (b) overlapping elemental intensities, and (c-f) measured (c) Ti $K$, (d) Si $K$, (e) Au M, and (f) $\mathrm{Ag} L$ intensities for the corresponding EDX mappings of $\mathrm{Au} / \mathrm{Ag}(4 / 1)$ catalyst in the region shown in (a).

elemental EDX mapping of the Au/Ag (4/1) catalyst (Fig. 8) reveals that most of the Ag species were distributed in the $\mathrm{Au}$ domain and were clearly distinguishable. The $\mathrm{Si}$ and Ti species were equidistributed, and the $\mathrm{Au}$ and $\mathrm{Ag}$ species overlapped in the $\mathrm{Au}-\mathrm{Ag} / \mathrm{TS}-1$ catalysts. The close integration of $\mathrm{Au}$ and $\mathrm{Ag}$ may be the origin of the synergistic effect.

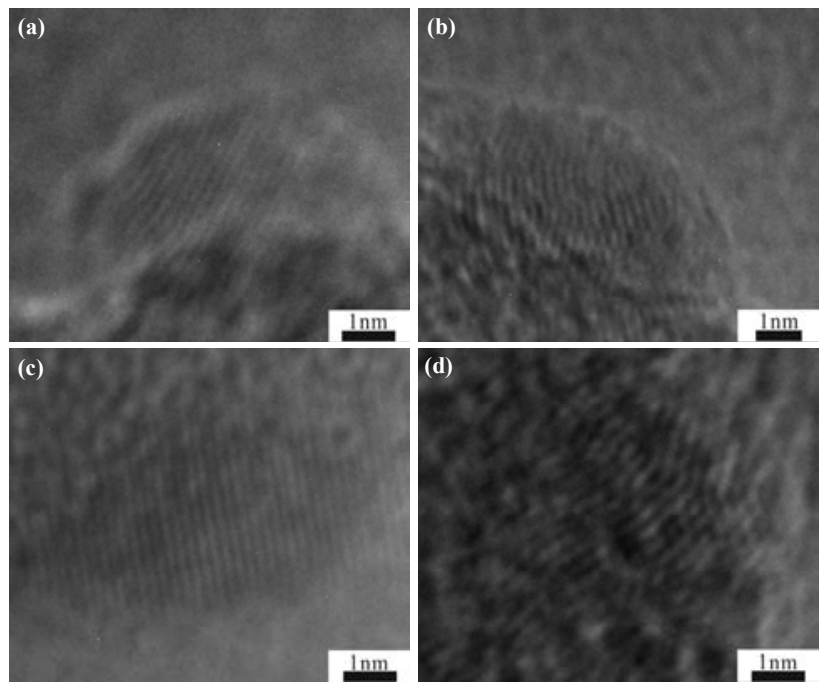

Fig. 9. HRTEM images of Au/Ag-modified TS- 1 for the following $\mathrm{Au} / \mathrm{Ag}$ mass ratios. (a) 1/0; (b) 4/1; (c) 1/1; (d) 2/3. 

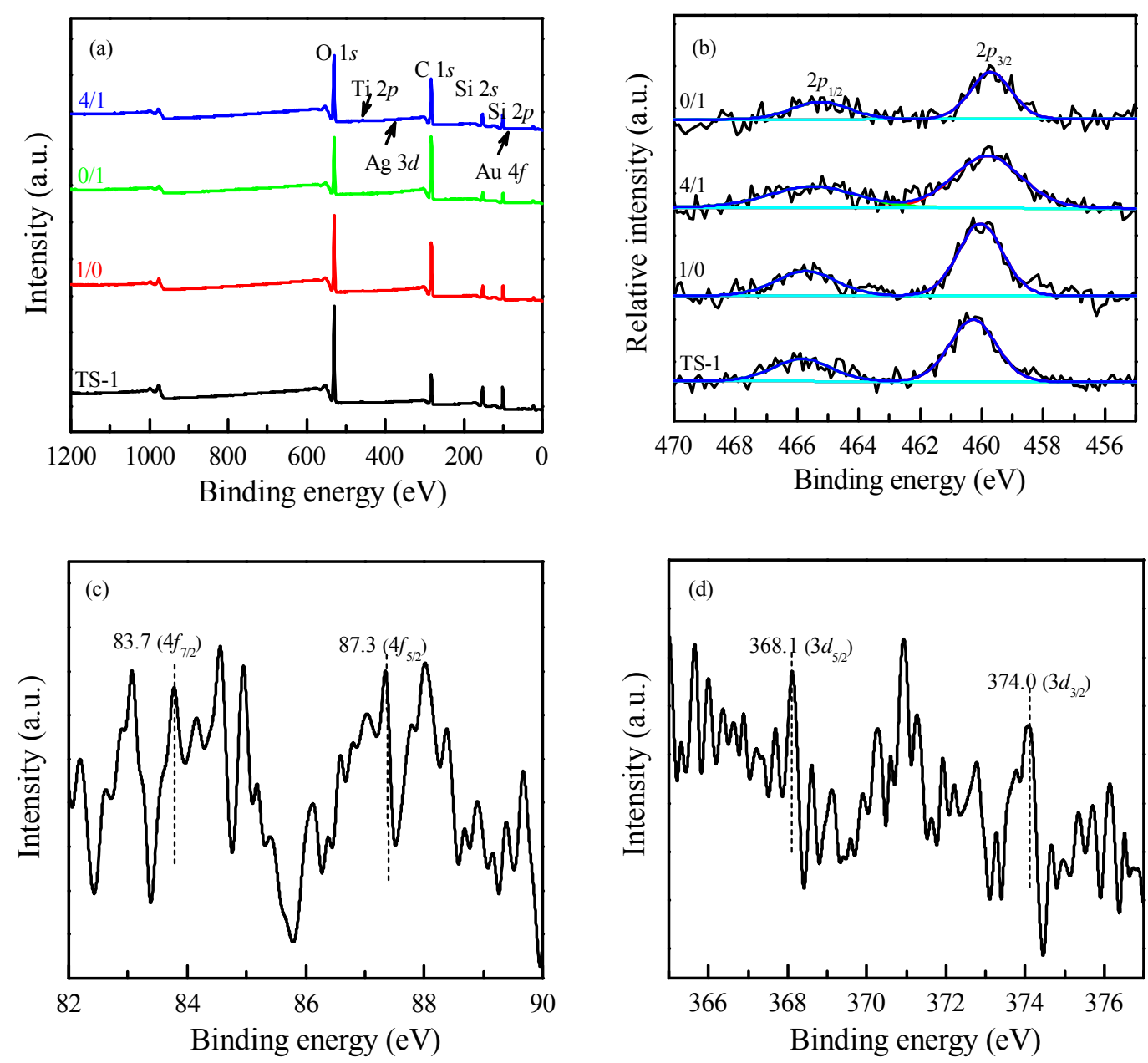

Fig. 10. XPS spectra. (a) Survey spectrum; (b) Ti 2p; (c) Au 4f: $\mathrm{Au} / \mathrm{Ag}=1 / 0$; (d) $\mathrm{Ag} 3 d$ : $\mathrm{Au} / \mathrm{Ag}=0 / 1$.

\subsubsection{XPS spectra}

To further investigate the element state and interaction between metal nanoparticles and TS-1, XPS spectra were obtained, and the results are presented in Fig. 10. O, Ti, Si, C, Au, and Ag were detected in TS- 1 and TS-1 with different $\mathrm{Au} / \mathrm{Ag}$ mass ratios $(1 / 0,4 / 1,0 / 1)$ catalysts, as shown in Fig. 10(a). The binding energies of Ti $2 p$ are presented in Fig. 10(b) for the above catalysts, and the peaks at 460 and $465.8 \mathrm{eV}$ were well defined for TS-1. The peak at $460 \mathrm{eV}$ is usually attributed to $\mathrm{Ti}$ in tetrahedral coordination [51]. With the metal loading, the binding energy of Ti $2 p_{3 / 2}$ shifted down by 0.4 and $0.5 \mathrm{eV}$ for $\mathrm{Au} / \mathrm{Ag}$ mass ratios of $4 / 1$ and $0 / 1$, respectively, which is explained by the greater tendency of Ag to conduct electrons between a metal and support because of its low work function. The work function of $\mathrm{Ag}(4.26 \mathrm{eV})$ is lower than that of the support ( $4.78 \mathrm{eV}$ ); therefore, the electrons have the tendency to aggregate on the support, which leads to the decrease of the binding energy. For the $\mathrm{Au}-\mathrm{Ag}$ bimetal, $\mathrm{Au}$ has a higher work function $(5.1 \mathrm{eV})$, which inhibits electron transfer; therefore, the shift decreases compared with that of monometallic Ag. This phenomenon indicates the generation of a new surface of Ti metal, which promotes electron transfer and is favorable for photocatalytic propene epoxidation. Fig. 10 (c) shows the theoretical binding energies of $\mathrm{Au} 4 f_{7 / 2}$ and $4 f_{5 / 2}$ for Au/TS-1. The theoretical binding energies of $\mathrm{Ag} 3 d_{5 / 2}$ and $3 d_{3 / 2}$ for $\mathrm{Ag} / \mathrm{TS}-1$ are shown in Fig. 10(d). The peak intensities for $\mathrm{Au}$ and $\mathrm{Ag}$ were near the background because of the small loadings of $\mathrm{Au}$ and Ag. It is difficult to clarify the forms of Au and Ag because of their small loadings. They may be assumed to be present in metal form because $\mathrm{Au}$ and $\mathrm{Ag}$ are more easily reduced in bimetallic catalysts under hydrogen [52].

\subsection{Photo-epoxidation of propylene to PO}

Typically, it takes 2-3 h to reach a steady state. To distinguish the thermal effect from the photocatalytic process, an epoxidation experiment was performed over TS-1 under different lighting conditions (with and without UV light). No activity was observed with UV illumination, as demonstrated by the results in Table 2. Therefore, the epoxidation over the catalyst was clearly photocatalytic epoxidation. In addition, with metal loading, $\mathrm{PO}$ and $\mathrm{CO}_{2}$ were not detected at the different temperatures without UV illumination. Table 3 summarizes the results of the photocatalytic epoxidation of propylene with oxygen over various samples in a continuous packed-bed reactor at 
Table 2

PO formation rates $(\mu \mathrm{mol} /(\mathrm{g} \cdot \mathrm{h}))$ over TS-1 for various lighting conditions and temperatures.

\begin{tabular}{lcccccccccc}
\hline Temperature (K) & 323 & 343 & 363 & 383 & 403 & 423 & 443 & 453 & 463 & 473 \\
\hline UV-light & 37.5 & 40.4 & 42.3 & 44.0 & 47.9 & 50.5 & 52.5 & 53.5 & 52.7 & 50.9 \\
No UV-light & ND & ND & ND & ND & ND & ND & ND & ND & ND & ND \\
\hline
\end{tabular}

ND: not detected by gas chromatography.

various temperatures with UV light excitation. The formation rate of PO ranged from 37.5 to $68.3 \mu \mathrm{mol} / \mathrm{g} \cdot \mathrm{h}$ and the PO selectivity ranged from $16.5 \%$ to $53.0 \%$. In addition to $\mathrm{PO}$, AA was detected as major by-product and $\mathrm{AL}, \mathrm{PA}, \mathrm{AC}$, and $\mathrm{EtOH}$ were detected as minor by-products. Interestingly, Fig. 11(a) reveals that the bimetallic catalyst with an $\mathrm{Au} / \mathrm{Ag}$ mass ratio of $4: 1$ showed the best activity and demonstrated a collaborative effect for propylene epoxidation compared with the catalyst with monometallic loading. When the $\mathrm{Au} / \mathrm{Ag}$ mass ratio was increased from $4: 1$ to $1: 0$ or decreased from $4: 1$ to $1: 1$ or $2: 3$, the activity decreased. This phenomenon may be attributed to the metal particle size and bimetallic composition. For the bimetals, 4/1(Au/Ag) had the smallest particle size and provided the largest specific surface area, which are beneficial for reactant adsorption. In addition, with the incorporation of a small amount of $\mathrm{Ag}, 4 / 1(\mathrm{Au} / \mathrm{Ag})$ exhibited better electron transfer and an improved separation effect for photogenerated electrons and holes. Monometallic Ag exhibited a larger particle size (Table 1), which is unfavorable for this reaction. Although $\mathrm{Au}$ particles are small, electron transfer from the metal to adsorbate is difficult because of the high work function of Au. Detailed explanations are provided below.

\subsubsection{Effect of reaction temperature on photo-epoxidation activity}

Monotonic relationships were not observed for any of the photocatalysts between the reaction temperature and the PO formation rate or $\mathrm{C}_{3} \mathrm{H}_{6}$ conversion rate, as observed in Fig. 11. Instead, the activity first increased with increasing temperature (up to $443 \mathrm{~K}$ ) and then decreased from $443-473 \mathrm{~K}$. The photo-

Table 3

Selectivities for photo-epoxidation over $\mathrm{Au}-\mathrm{Ag} / \mathrm{TS}-1$ for photocatalysts with various $\mathrm{Au} / \mathrm{Ag}$ mass ratios at various temperatures.

\begin{tabular}{|c|c|c|c|c|c|c|c|c|c|c|}
\hline \multirow{2}{*}{ Entry } & \multirow{2}{*}{ Catalyst } & \multirow{2}{*}{$\begin{array}{c}\text { Temperature } \\
(\mathrm{K})\end{array}$} & \multirow{2}{*}{$\begin{array}{l}\mathrm{C}_{3} \mathrm{H}_{6} \text { conversion } \\
\text { rate }(\mu \mathrm{mol} /(\mathrm{g} \cdot \mathrm{h}))\end{array}$} & \multirow{2}{*}{$\begin{array}{l}\text { PO formation rate } \\
(\mu \mathrm{mol} /(\mathrm{g} \cdot \mathrm{h}))\end{array}$} & \multicolumn{6}{|c|}{ Selectivity (\%) } \\
\hline & & & & & $\mathrm{AA}$ & EtOH & $\mathrm{PO}$ & $\mathrm{AL}$ & $\mathrm{PA}$ & $\mathrm{AC}$ \\
\hline \multirow[t]{10}{*}{1} & TS-1 & 323 & 72.1 & 37.5 & 48.0 & trace & 52.0 & trace & ND & ND \\
\hline & & 343 & 168.3 & 40.4 & 22.8 & 20.3 & 24.0 & 16.5 & ND & 16.3 \\
\hline & & 363 & 215.3 & 42.3 & 20.8 & 16.7 & 20.6 & 13.9 & 13.4 & 14.6 \\
\hline & & 383 & 249.1 & 44.0 & 27.8 & 14.2 & 18.4 & 13.8 & 13.5 & 12.3 \\
\hline & & 403 & 266.7 & 47.9 & 32.4 & 12.7 & 18.3 & 13.7 & 12.1 & 10.8 \\
\hline & & 423 & 279.4 & 50.5 & 33.4 & 11.8 & 18.1 & 13.6 & 13.0 & 10.1 \\
\hline & & 443 & 296.6 & 52.5 & 34.2 & 11.3 & 17.7 & 13.3 & 13.6 & 9.9 \\
\hline & & 453 & 295.7 & 53.5 & 34.9 & 10.7 & 17.5 & 13.9 & 13.7 & 9.3 \\
\hline & & 463 & 290.3 & 52.7 & 34.7 & 10.7 & 17.2 & 14.1 & 13.9 & 9.4 \\
\hline & & 473 & 288.7 & 50.9 & 33.7 & 10.5 & 16.7 & 14.5 & 15.4 & 9.2 \\
\hline \multirow[t]{10}{*}{2} & $\mathrm{Au} / \operatorname{Ag}(1 / 0)$ & 323 & 71.9 & 37.8 & 47.4 & trace & 52.6 & trace & ND & ND \\
\hline & & 343 & 170.3 & 40.9 & 23.7 & 19.4 & 24.7 & 16.8 & ND & 15.4 \\
\hline & & 363 & 220.2 & 48.4 & 28.2 & 18.6 & 22.0 & 16.1 & ND & 15.1 \\
\hline & & 383 & 264.0 & 53.6 & 31.6 & 12.5 & 20.3 & 13.9 & 11.1 & 10.5 \\
\hline & & 403 & 291.7 & 59.8 & 32.6 & 12.0 & 20.5 & 13.8 & 11.4 & 9.7 \\
\hline & & 423 & 304.8 & 62.6 & 32.8 & 11.5 & 20.5 & 13.8 & 11.9 & 9.5 \\
\hline & & 443 & 310.5 & 64.9 & 32.6 & 10.7 & 20.9 & 14.3 & 12.4 & 9.1 \\
\hline & & 453 & 306.3 & 62.8 & 32.4 & 10.6 & 20.5 & 14.8 & 12.6 & 9.1 \\
\hline & & 463 & 304.4 & 61.2 & 31.5 & 10.8 & 20.1 & 15.1 & 13.6 & 8.9 \\
\hline & & 473 & 302.5 & 59.0 & 31.3 & 10.3 & 19.5 & 15.4 & 14.8 & 8.7 \\
\hline \multirow[t]{10}{*}{3} & $\mathrm{Au} / \operatorname{Ag}(4 / 1)$ & 323 & 74.1 & 38.8 & 47.7 & trace & 52.3 & trace & ND & ND \\
\hline & & 343 & 172.5 & 41.4 & 23.2 & 20.1 & 24.0 & 16.4 & ND & 16.3 \\
\hline & & 363 & 237.6 & 50.1 & 21.8 & 15.9 & 21.1 & 14.3 & 13.4 & 13.5 \\
\hline & & 383 & 294.6 & 60.4 & 33.2 & 11.3 & 20.5 & 14.2 & 10.9 & 9.9 \\
\hline & & 403 & 315.0 & 64.9 & 33.7 & 10.6 & 20.6 & 14.1 & 11.5 & 9.5 \\
\hline & & 423 & 327.5 & 67.8 & 34.3 & 10.1 & 20.7 & 14.0 & 11.6 & 9.3 \\
\hline & & 443 & 333.1 & 68.3 & 34.3 & 9.9 & 20.5 & 14.2 & 12.2 & 8.9 \\
\hline & & 453 & 349.7 & 66.1 & 34.3 & 9.8 & 18.9 & 14.7 & 13.4 & 8.8 \\
\hline & & 463 & 341.3 & 63.5 & 33.5 & 10.0 & 18.6 & 15.0 & 14.1 & 8.7 \\
\hline & & 473 & 339.3 & 60.4 & 32.7 & 10.0 & 17.8 & 15.8 & 14.9 & 8.7 \\
\hline
\end{tabular}


Table 3 (continued)

\begin{tabular}{|c|c|c|c|c|c|c|c|c|c|c|}
\hline \multirow{2}{*}{ Entry } & \multirow{2}{*}{ Catalyst } & \multirow{2}{*}{$\begin{array}{l}\text { Temperature } \\
\text { (K) }\end{array}$} & \multirow{2}{*}{$\begin{array}{c}\mathrm{C}_{3} \mathrm{H}_{6} \text { conversion } \\
\text { rate }(\mu \mathrm{mol} /(\mathrm{g} \cdot \mathrm{h}))\end{array}$} & \multirow{2}{*}{$\begin{array}{c}\text { PO formation rate } \\
(\mu \mathrm{mol} /(\mathrm{g} \cdot \mathrm{h}))\end{array}$} & \multicolumn{6}{|c|}{ Selectivity (\%) } \\
\hline & & & & & AA & EtOH & PO & $\mathrm{AL}$ & $\mathrm{PA}$ & $\mathrm{AC}$ \\
\hline \multirow[t]{10}{*}{$\overline{4}$} & $\mathrm{Au} / \mathrm{Ag}(2 / 3)$ & 323 & 71.2 & 37.6 & trace & trace & 52.8 & trace & trace & trace \\
\hline & & 343 & 151.8 & 40.7 & 23.2 & 19.4 & 26.8 & 16.0 & ND & 14.6 \\
\hline & & 363 & 210.2 & 44.5 & 23.2 & 15.1 & 21.1 & 14.2 & 13.2 & 13.2 \\
\hline & & 383 & 245.6 & 52.3 & 29.6 & 13.3 & 20.5 & 13.5 & 11.7 & 11.4 \\
\hline & & 403 & 263.2 & 54.5 & 30.6 & 13.0 & 20.7 & 13.5 & 11.7 & 10.5 \\
\hline & & 423 & 272.5 & 56.7 & 31.0 & 12.4 & 20.8 & 13.5 & 12.0 & 10.3 \\
\hline & & 443 & 273.8 & 57.5 & 30.6 & 12.2 & 21.0 & 13.7 & 12.4 & 10.1 \\
\hline & & 453 & 270.1 & 57.2 & 30.4 & 12.1 & 21.1 & 14.3 & 12.2 & 9.9 \\
\hline & & 463 & 267.6 & 56.2 & 30.0 & 12.1 & 21.0 & 14.6 & 12.4 & 9.9 \\
\hline & & 473 & 270.9 & 54.1 & 29.7 & 12.2 & 20.5 & 15.1 & 12.5 & 10.0 \\
\hline \multirow[t]{10}{*}{5} & $\mathrm{Au} / \mathrm{Ag}(1 / 1)$ & 323 & 71.3 & 37.8 & 47.0 & trace & 53.0 & trace & ND & ND \\
\hline & & 343 & 131.4 & 40.5 & 28.5 & trace & 30.8 & 21.3 & ND & 19.4 \\
\hline & & 363 & 196.1 & 45.7 & 30.1 & trace & 23.3 & 16.9 & 15.7 & 14.0 \\
\hline & & 383 & 260.3 & 52.6 & 31.0 & 12.6 & 19.6 & 14.6 & 11.4 & 10.8 \\
\hline & & 403 & 283.4 & 56.4 & 31.4 & 12.7 & 19.9 & 13.7 & 12.2 & 10.6 \\
\hline & & 423 & 301.1 & 59.6 & 33.0 & 11.4 & 19.8 & 13.5 & 12.7 & 9.6 \\
\hline & & 443 & 297.5 & 60.4 & 33.1 & 11.0 & 20.3 & 13.7 & 12.4 & 9.5 \\
\hline & & 453 & 298.5 & 59.8 & 32.7 & 11.0 & 20.3 & 14.0 & 12.5 & 9.4 \\
\hline & & 463 & 293.4 & 58.7 & 32.2 & 11.0 & 20.0 & 14.3 & 13.2 & 9.3 \\
\hline & & 473 & 289.8 & 55.1 & 31.4 & 11.5 & 19.0 & 14.8 & 13.6 & 9.7 \\
\hline \multirow[t]{10}{*}{6} & $\mathrm{Au} / \mathrm{Ag}(0 / 1)$ & 323 & 71.5 & 37.6 & 47.4 & trace & 52.6 & trace & ND & ND \\
\hline & & 343 & 135.3 & 40.6 & 29.0 & trace & 30.0 & 21.1 & ND & 19.9 \\
\hline & & 363 & 205.6 & 44.0 & 29.4 & trace & 21.4 & 17.3 & 16.3 & 15.6 \\
\hline & & 383 & 238.1 & 48.1 & 29.4 & 13.1 & 20.2 & 14.2 & 11.9 & 11.2 \\
\hline & & 403 & 261.3 & 52.8 & 30.7 & 12.7 & 20.2 & 13.9 & 12.1 & 10.4 \\
\hline & & 423 & 272.2 & 55.0 & 31.3 & 12.4 & 20.2 & 13.7 & 12.2 & 10.2 \\
\hline & & 443 & 271.4 & 56.2 & 31.0 & 11.9 & 20.7 & 14.1 & 12.4 & 9.9 \\
\hline & & 453 & 269.9 & 55.2 & 30.4 & 11.9 & 20.3 & 14.4 & 13.0 & 10.0 \\
\hline & & 463 & 266.0 & 54.0 & 30.0 & 12.0 & 20.0 & 14.7 & 13.4 & 9.9 \\
\hline & & 473 & 268.9 & 51.9 & 29.7 & 12.0 & 19.3 & 15.0 & 14.1 & 9.9 \\
\hline
\end{tabular}

ND: not detected by gas chromatography.

AA: acetaldehyde; EtOH: ethanol; PO: propylene oxide; AL: acrolein; PA: propionaldehyde; AC: acetone.

reaction is often a light-driven rather than a thermally induced process. Kim et al. [53] reported that the true activation energy is nil in a photoreaction. Therefore, the activation energy is the apparent activation energy, which is very small. Hence, desorption of the final product and reactant adsorption will become important factors for this reaction. Desorption and adsorption are endothermic and exothermic processes, respectively. In

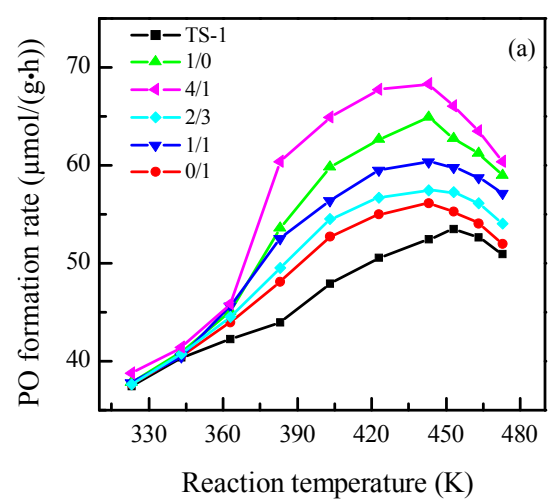

other words, increasing the temperature favors desorption of the photocatalytic reaction products, which enhances the reaction efficiency by releasing more active sites for reaction. However, increasing the temperature may suppress propylene adsorption on photocatalysts, which may reduce the reaction efficiency. Therefore, the reaction temperature has competing effects on the reaction rate in this study. During the

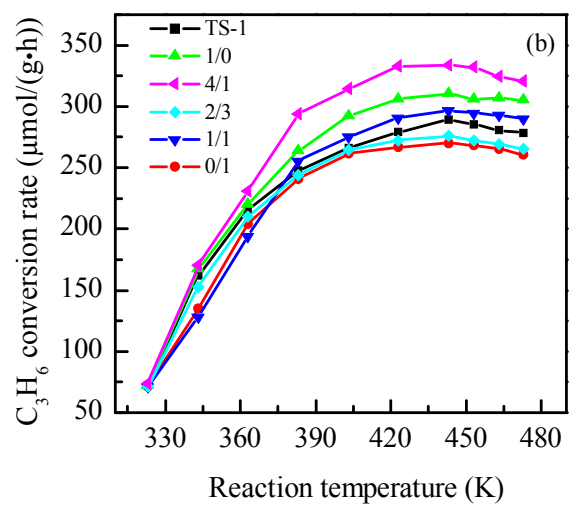

Fig. 11. Correlation between reaction temperature and $\mathrm{PO}$ formation rate (a) and $\mathrm{C}_{3} \mathrm{H}_{6}$ consumption rate (b) for photocatalysts with various $\mathrm{Au} / \mathrm{Ag}$ mass ratios. 

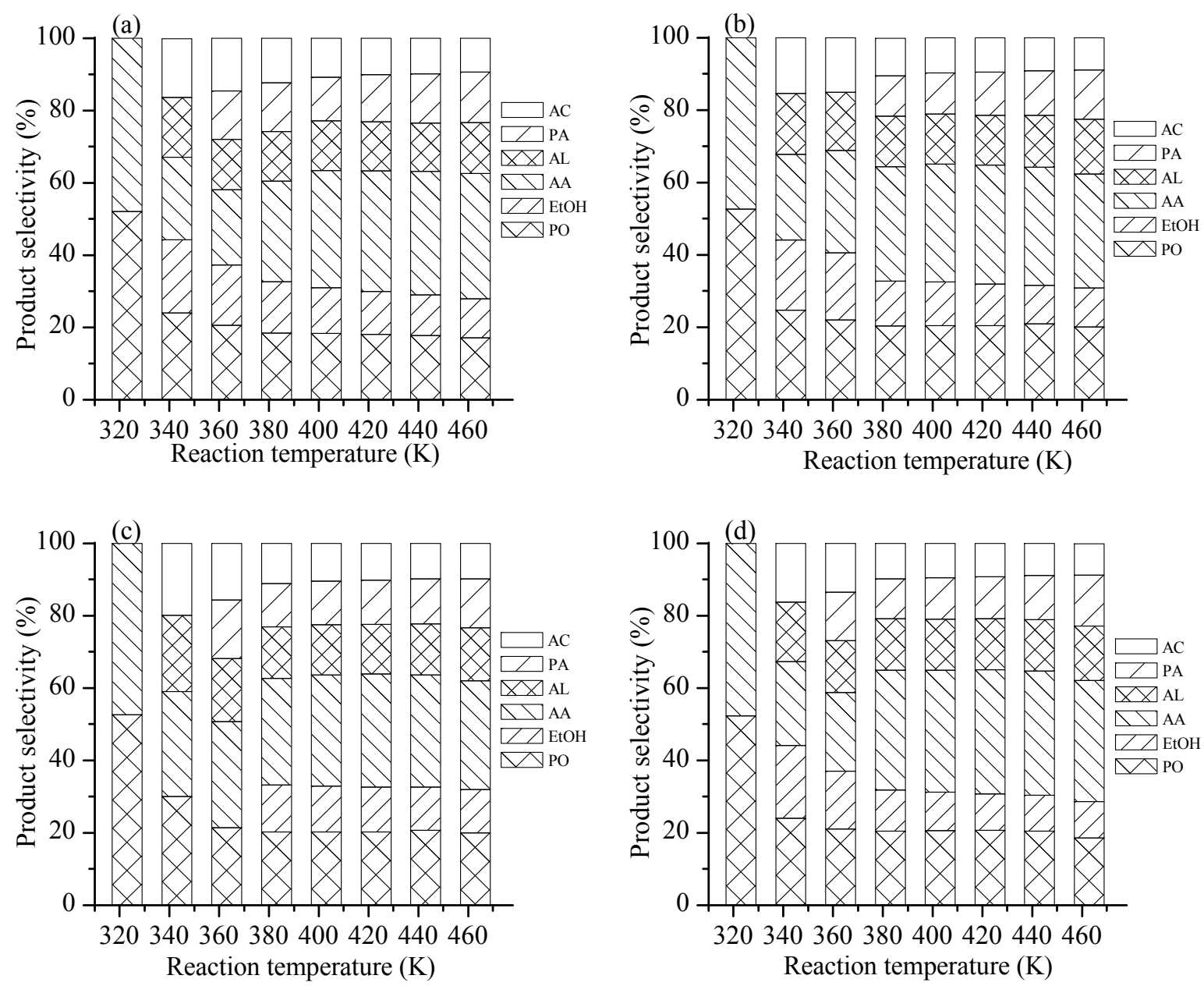

Fig. 12. Correlation between reaction temperature and product selectivity for TS-1 (a) and TS- 1 modified with Au/Ag mass ratios of $1 / 0$ (b), $0 / 1$ (c), and $4 / 1(d)$.

low-temperature period, propylene adsorption is dominant, and the product desorption rate increases with increasing temperature; therefore, the PO formation rate monotonically increases. However, when the temperature increases above $412 \mathrm{~K}$, product adsorption is the rate-determining step, and high temperature is unfavorable for propylene adsorption. Therefore, the PO formation rate decreases with increasing temperature. Fig. 11(a) demonstrates that the $\mathrm{Au}-\mathrm{Ag} / \mathrm{TS}-1(4 / 1)$ catalyst at $443 \mathrm{~K}$ exhibits an optimal PO formation rate of $68.3 \mu \mathrm{mol} / \mathrm{g} \cdot \mathrm{h}$. Fig. 12 shows the product distribution for various temperatures for TS- 1 and TS- 1 modified with $\mathrm{Au} / \mathrm{Ag}$ mass ratios of $1 / 0,0 / 1$, and $4 / 1$. High temperature led to low PO selectivity and high selectivity to the by-products, which may be attributed to the competition of multiple reactions toward different products. Nguyen et al. [54] reported that high temperature inhibits the formation of hydroxyl radical $\mathrm{OH}^{*}$ (ads) intermediates, which are generated from water molecules. Therefore, high temperature will restrain the conversion of PA into propionic acid $\left(\mathrm{C}_{2} \mathrm{H}_{5} \mathrm{COOH}\right)^{-}$, the intermediate product of EtOH, resulting in an increase of $\mathrm{PA}$ and decrease of EtOH with increasing temperature. These researchers also noted that heating may increase not only the desorption of photocatalytic products but also the partial oxidation and/or total oxidation of the intermediates. Therefore, the product distribution would be rearranged.

\subsubsection{Effect of $A u / A g$ loading on photo-epoxidation}

Fig. 11 reveals that loading with the monometal or bimetal resulted in similar activity and selectivity as those of TS-1 at low temperature (from 323 to $343 \mathrm{~K}$ ). Above $343 \mathrm{~K}$, loading with the monometal or bimetal greatly increased the PO formation rates. This phenomenon may be connected with reactant adsorption, product desorption, and photon utilization. Low temperature is beneficial for reactant adsorption but unfavorable for product desorption, which inhibits the reaction efficiency by occupying more active sites for the reaction [54]. Although the introduction of Ag to Au will affect its physical and chemical properties, which is beneficial for photo-epoxidation by improving the oxygen adsorption, activation, and electron transfer $[26,27,46]$, photogenerated electron utilization is suppressed because of the limited active sites. Therefore, during the low-temperature period, loading with the 
monometal or bimetal limits enhancement of the photoreaction performance. With increasing temperature, the product desorption rate increases and more active sites are released. Therefore, efficient electronic transmission and utilization are crucial for this reaction. The addition of $\mathrm{Ag}$ to $\mathrm{Au}$ is beneficial for electron transfer [46]; thus, bimetal loading should enhance the photocatalytic activity compared with monometal loading and TS-1. In Fig. 11, the performance of the Au/Ag (4/1) bimetallic catalyst is consistent with the above analysis. However, with increasing Ag content in the bimetal, the photocatalytic activity decreased, which can be explained by the chemical properties and particle size of the bimetal. As previously mentioned, the physical and chemical properties of the bimetal are affected by the introduction of $\mathrm{Ag}$ to $\mathrm{Au}[26,27,46]$. In addition, the particle size is an important factor in the photocatalytic reaction. Although the addition of Ag is beneficial for this reaction, the metal particle size (Table 1) greatly increased from 2.1 to $4.2 \mathrm{~nm}$ with increasing Ag content, which is adverse for the reaction [21-23]. The catalytic activity has the trend $4 / 1(\mathrm{Au} / \mathrm{Ag})>1 / 0>1 / 1>2 / 3>0 / 1>\mathrm{TS}-1$. For an $\mathrm{Au} / \mathrm{Ag}$ mass ratio of $4 / 1$, the highest reaction rate $(68.3 \mu \mathrm{mol} / \mathrm{g} \cdot \mathrm{h})$ is attained, which is higher than the rates previously reported for $\mathrm{Au} / \mathrm{TiO}_{2}$ and $\mathrm{Au} / \mathrm{TS}-1$ [55]. The fact that the particle size becomes large for all the photocatalysts containing Ag suggests that aggregation occurred during the calcination process. Table 3 demonstrates that monometal or bimetal loading enhances the selectivity to PO compared with that of pristine TS- 1 . The optimal selectivity to PO below $363 \mathrm{~K}$ was reached for $\mathrm{Au} / \mathrm{Ag}=$ $1 / 1$ and was higher than that achieved with monometallic modification. Above $363 \mathrm{~K}$, the selectivity of the bimetal was equivalent to that of the monometal. In other words, the bimetal plays an essential role in determining the formation rate, selectivity of $\mathrm{PO}$, and product distribution.

\subsection{Proposed reaction mechanism on $\mathrm{Au} / \mathrm{Ag}-\mathrm{TS}-1$ photocatalysts}

It is well-documented that tetrahedrally coordinated Ti(IV) within the framework of TS-1 plays a critical role in the photocatalytic epoxidation of propylene. As previously discussed, the UV-vis and XPS results suggest that Ti oxides were mainly dispersed in the microporous materials as isolated tetrahedrally coordinated metal oxides. The structures were reported to be easily excited under UV-light irradiation to reach the corresponding charge-transfer excited state, which includes electron transfer from $\mathrm{O}^{2-}$ to $\mathrm{Ti}^{4+}$ species [56]:

$$
\left(\mathrm{Ti}^{4+}-\mathrm{O}_{\mathrm{L}}{ }^{2-}\right)+\mathrm{h} v \rightarrow\left(\mathrm{Ti}^{3+}-\mathrm{O}_{\mathrm{L}}^{-}\right)^{*}
$$

Murata et al. [56] proposed that $\mathrm{O}_{2}$, rather than $\mathrm{C}_{3} \mathrm{H}_{6}$, was activated on the charge transferred $\left(\mathrm{Ti}^{3+}-\mathrm{O}_{\mathrm{L}}{ }^{-}\right)$radical pair. They concluded that the active oxygen species for PO production was an electrophilic $\mathrm{O}_{3}{ }^{-}\left(\mathrm{O}_{2}{ }^{+} \ldots \mathrm{O}^{2-}\right)$ species generated on the photoformed hole center $[56,57]$. Because the photoinduced electron in $\mathrm{Ti}^{3+}$ is consumed by molecular oxygen $\left(\mathrm{Ti}^{3+}+\mathrm{O}_{2} \rightarrow \mathrm{Ti}^{4+}\right.$ $+\mathrm{O}_{2}{ }^{\circ}$ ), the oxidation state of $\mathrm{Ti}^{4+}$ is actually constant in the presence of oxygen. The generated active species $\left(\mathrm{O}_{2}{ }^{\circ}\right)$ and $\left(\mathrm{O}_{3}{ }^{-}\right)$were thought to react with $\mathrm{C}_{3} \mathrm{H}_{6}$ to generate $\mathrm{PO}$ and its co-products [58]. According to the above analysis, the UV-light excitation and photo-epoxidation processes are suitable for our photocatalytic system.

$\mathrm{Au}$ binds oxygen very weakly, and oxygen activation is generally thought to be a rate-limiting step for most oxidation reactions catalyzed by Au nanoparticles [59-61]. Kondarides et al. [62] observed that Au and Ag bimetal facilitated oxygen adsorption by decreasing the activation energy for molecular oxygen adsorption. Wang et al. [46] also proposed that $\mathrm{O}_{2}{ }^{-}$ formation via dioxygen activation on $\mathrm{Au}-\mathrm{Ag}$ was more facile than on Ag alone. Sandoval et al. [52] proposed that the bimetal easily adsorbed and activated oxygen with the change of the electronic and geometric structure of Au-based catalysts with the introduction of Ag atoms. In addition, the difficulty of electron transfer on the $\mathrm{Au}(111)$ surface because of its high work function [63] was alleviated by the modified electronic properties of $\mathrm{Au}$ with the introduction of $\mathrm{Ag}$ as a powerful electron donor. Therefore, a greater tendency for electron transfer between the support and bimetal is achieved, as demonstrated by the UV-vis and XPS analyses. The PL spectra also confirmed that the bimetal inhibits the recombination of photoinduced electrons and holes. Therefore, the $\mathrm{Au}-\mathrm{Ag}$ bimetals provide a synergistic effect for this photoreaction. In addition, the epoxidation reaction is also connected to the reaction temperature. For the low-temperature period, product desorption is inhibited, which occupies more active sites, leading to limited photogenerated electron utilization. Therefore, the synergetic effect of bimetal catalysts is limited. With increasing temperature, more active sites are released, and the bimetal results in an obvious synergetic effect (Fig. 11), which is explained by the improved reactant adsorption, activation, and separation of photoinduced electrons and holes resulting from the introduction of the bimetal. In our photocatalytic system, the surface plasmon resonance effect of metals $(\mathrm{Au}, \mathrm{Ag})$ was easily induced under light excitation $(\lambda=200-600 \mathrm{~nm})$ and was favorable for propylene epoxidation. The reaction mechanism could be explained by the excited electrons of the metal reacting with $\mathrm{O}_{2}$ directly or transferring from the metal to TS- 1 and then participating in the reaction. Based on these findings, we propose a mechanism for the photo-epoxidation of propylene over $\mathrm{Au}-\mathrm{Ag} / \mathrm{TS}-1$ photocatalysts, as illustrated in Fig. 13. Under UV-light irradiation, the generated electrons and holes are

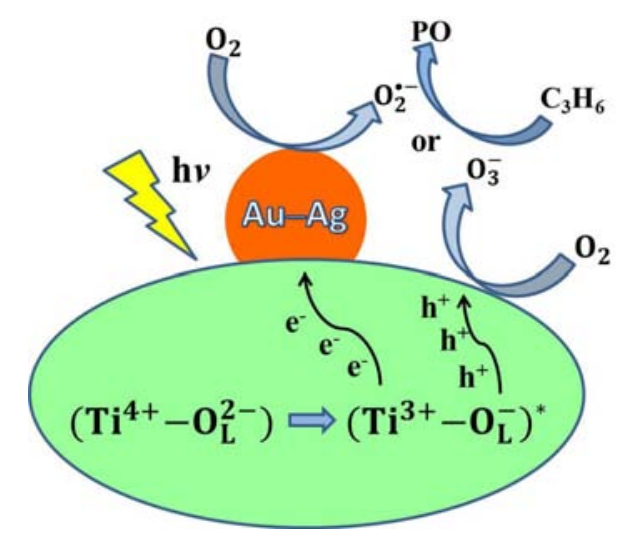

Fig. 13. Proposed mechanism for the synergetic photo-epoxidation of propylene over $\mathrm{Au}-\mathrm{Ag} / \mathrm{TS}-1$ photocatalysts. 
captured by $\mathrm{O}_{2}$ to produce $\mathrm{O}_{3}{ }^{-}$and $\mathrm{O}_{2}{ }^{--}$active species, which react with $\mathrm{C}_{3} \mathrm{H}_{6}$ to generate $\mathrm{PO}$ and other by-products. During the photo-epoxidation, the $\mathrm{Au} / \mathrm{Ag}$ mass ratio and reaction temperature greatly affect the catalytic activity and selectivity.

In this study, direct photo-epoxidation of propylene with $\mathrm{O}_{2}$ was studied as a potential method for the green production of PO. This is the first time that Au-Ag bimetal has been used for the photo-epoxidation of propylene. Although some improvement of the catalytic activity was achieved for photocatalytic epoxidation, the results remain far from those needed for large-scale production. Therefore, the development of new photocatalyst systems is needed to further improve the photo-epoxidation.

\section{Conclusions}

$\mathrm{Au}$-Ag-supported TS-1 materials were prepared using a facile two-step method, and the resulting materials were characterized using nitrogen adsorption, XRD, XPS, UV-vis, PL, SEM, and TEM and served as catalysts for propylene epoxidation. Compared with the monometallic catalytic activity, those of the bimetals showed unusual activity profiles as a function of composition and temperature. It was suggested that the addition of Ag promoted the adsorption and activation of oxygen by decreasing the activation energy for molecular adsorption of oxygen. In addition, the bimetals showed an excellent ability to transfer electrons between the support and bimetal and inhibited the recombination of photoinduced electrons and holes. A mechanism was proposed to explain this behavior, in which the alternatively intimate contact between $\mathrm{Au}$ and $\mathrm{Ag}$ provides synergism for activating $\mathrm{O}_{2}$ and propylene, resulting in a strongly synergistic effect for propylene epoxidation. The best-performing $\mathrm{Au}-\mathrm{Ag}$ bimetallic catalyst had a nominal
$\mathrm{Au} / \mathrm{Ag}$ mass ratio of 4:1.

\section{References}

[1] D. L. Trent, Kirk-Othmer Encyclopedia of Chemical Technology, John Wiley \& Sons, Inc., 2000.

[2] T. A. Nijhuis, M. Makkee, J. A. Moulijn, B. M. Weckhuysen, Ind. Eng. Chem. Res., 2006, 45, 3447-3459.

[3] Z. H. Suo, M. S. Jin, J. Q. Lu, Z. B. Wei, C. Li, J. Nat. Gas. Chem., 2008, $17,184-190$.

[4] G. J. Jin, G. Z. Lu, Y. L. Guo, Y. Guo, J. S. Wang, X. H. Liu, Catal. Today, 2004, 93-95, 173-182.

[5] F. Amano, T. anaka, T. Funabiki, Langmuir, 2004, 20, 4236-4240.

[6] T. Tanaka, H. Nojima, H. Yoshida, H. Nakagawa, T. Funabiki, S. Yoshida, Catal. Today, 1993, 16, 297-307.

[7] C. Murata, H. Yoshida, J. Kumagai, T. Hattori, J. Phys. Chem. B, 2003, 107, 4364-4373.

[8] H. Yoshida, T. Shimizu, C. Murata, T. Hattori, J. Catal., 2003, 220, 226-232.

[9] H. Yoshida, T. Tanaka, M. Yamamoto, T. Yoshida, T. Funabiki, S. Yoshida, J. Catal., 1997, 171, 351-357.

[10] J. L. He, Q. G. Zhai, Q. H. Zhang, W. P. Deng, Y. Wang, J. Catal., 2013, 299, 53-66.

[11] M. Haruta, B. S. Uphade, S. Tsubota, A. Miyamoto, Res. Chem. Intermed., 1998, 24, 329-336.

[12] Y. A. Kalvachev, T. Hayashi, S.Tsubota, M. Haruta, Stud. Surf. Sci. Catal., 1997, 110, 965-972.

[13] Y. A. Kalvachev, T. Hayashi, S. Tsubota, M. Haruta, J. Catal., 1999, 186, 228-233.

[14] B. S. Uphade, S. Tsubota,T. Hayashi, M. Haruta, Chem. Lett., 1998, 1277-1278.

[15] B. S. Uphade, M. Okumura, S. Tsubota, M. Haruta, Appl. Catal. A, 2000, 190, 43-50.

[16] B. S. Uphade, M. Okumura, N. Yamada, S. Tsubota, M. Haruta, Stud. Surf. Sci. Catal., 2000, 130, 833-838.

\section{Graphical Abstract}

Chin. J. Catal., 2017, 38: 831-844 doi: 10.1016/S1872-2067(17)62832-8

\section{Synergetic photo-epoxidation of propylene with molecular oxygen over bimetallic $\mathrm{Au}-\mathrm{Ag} / \mathrm{TS}-1$ photocatalysts}

Naixu Li, Bin Yang, Ming Liu, Yong Chen, Jiancheng Zhou*

Southeast University; Southeast University Chengxian College
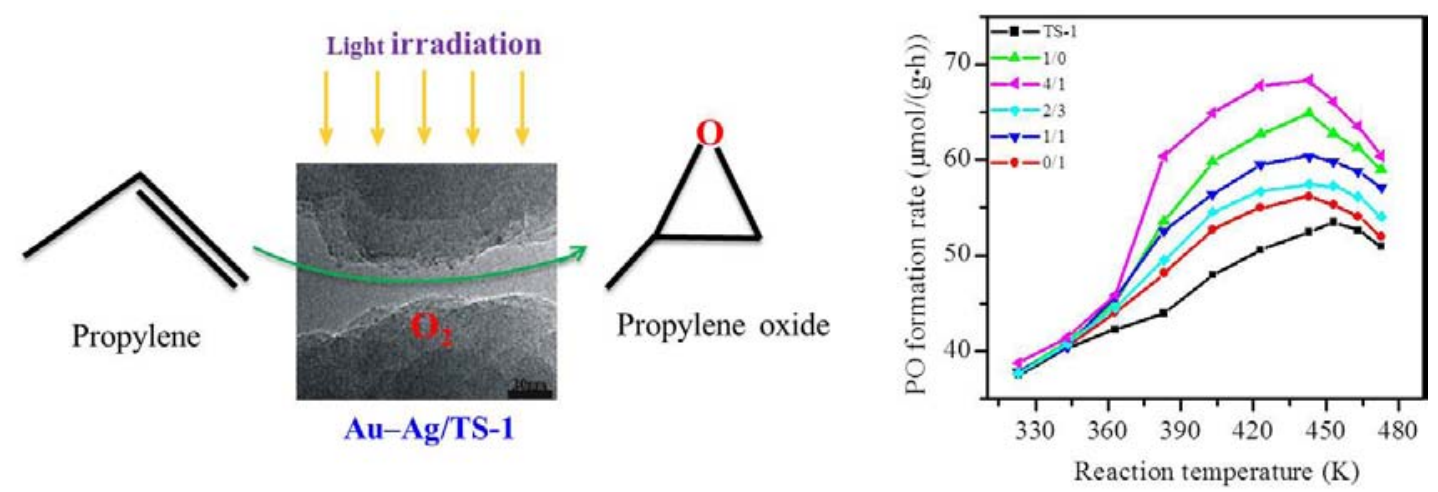

$\mathrm{Au}-\mathrm{Ag} / \mathrm{TS}-1$ bimetallic catalysts prepared using a hydrothermal-immersion method showed a synergetic effect for photo-epoxidation of propylene using $\mathrm{O}_{2}$ as the oxidant. 
[17] B. S. Uphade, Y. Yamada, T. Akita, T. Nakamura, M. Haruta, Appl. Catal. A, 2001, 215, 137-148.

[18] B. S. Uphade, T. Akita, T. Nakamura, M. Haruta, J. Catal., 2002, 209, 331-340.

[19] E. E. Stangland, K. B. Stavens, R. P. Andres, W. N. Delgass, J. Catal., 2000, 191, 332-347.

[20] E. E. Stangland, K. B. Stavens, R. P. Andres, W. N. Delgass, Stud. Surf. Sci. Catal., 2000, 130, 827-832.

[21] M. S. Chen, D. W. Goodman, Science., 2004, 306, 252-255.

[22] M. Haruta, Chem. Rec., 2003, 3, 75-87.

[23] H. Falsig, B. Hvolbæk, I. S. Kristensen, T. Jiang,T. Bligaard, C. H. Christensen, J. K. Nørskov, Angew. Chem. Int. Ed., 2008, 120, 4913-4917.

[24] Y. Wang, J. M. Zheng, K. Fan, W. L. Dai, Green Chem., 2011, 13, 1644-1647.

[25] C. L. Bracey, P. R. Ellis, G. J. Hutchings, Chem. Soc. Rev., 2009, 38, 2231-2243.

[26] H. Häkkinen, S. Abbet, A. Sanchez, U. Heiz, U. Landman, Angew. Chem. Int. Ed., 2003, 42, 1297-1300.

[27] A. M. Venezia, L. F. Liotta, G. Pantaleo, V. LaParola, G. Deganello, A. Beck, Z. Koppány, K. Frey, D. Horváth, L. Guczi, Appl. Catal. A, 2003, 251, 359-368.

[28] X. Y. Liu, A. Q. Wang, X. D. Wang, C. Y. Mou, T. Zhang, Chem. Commun., 2008, 3187-3189.

[29] X. Y. Liu, Y. N. Li, J. W. Lee, C. Y. Hong, C. Y. Mou, B. W. L. Jang, Appl. Catal. A, 2012, 439-440, 8-14.

[30] A. B. Smetana, K. J. Klabunde, C. M. Sorensen, A. A. Ponce, B. Mwale, J. Phys. Chem. B, 2006, 110, 2155-2158.

[31] P. G. N. Mertens, P. Vandezande, X. P. Ye, H. Poelman, I. F. J. Vankelecom, D. E. De Vos, Appl. Catal. A, 2009, 355, 176-183.

[32] J. H. Liu, A. Q. Wang, Y. S. Chi, H. P. Lin, C. Y. Mou, J. Phys. Chem. B, 2005, 109, 40-43.

[33] Y. Iizuka, A. Kawamoto, K. Akita, M. Daté, S. Tsubota, M. Okumura, M. Haruta, Catal. Lett, 2004, 97, 203-208.

[34] A. Sandoval, A. Aguilar, C. Louis, A. Traverse, R. Zanella, J. Catal., 2011, 281, 40-49.

[35] X. Yang, D. Chen, S. J. Liao, H. Y. Song, Y. W. Li, Z. Y. Fu, Y. L. Su, J. Catal., 2012, 291, 36-43.

[36] R. P. Doherty, J. M. Krafft, C. Méthivier, S. Casale, H. Remita, C. Louis, C. Thomas, J. Catal., 2012, 287, 102-113.

[37] A. Wittstock, V. Zielasek, J. Biener, C. M. Friend, M. Bäumer, Science, 2010, 327, 319-322.

[38] L. V. Moskaleva, S. Rohe, A. Wittstock, V. Zielasek, T. Kluner, K. M. Neyman, M. Baumer, Phys. Chem. Chem. Phys., 2011, 13,
4529-4539.

[39] R. B. Khomane, B. D. Kulkarni, A. Paraskar, S. R. Sainkar, Mater. Chem. Phys., 2002,76, 99-103.

[40] J. W. Zheng, H. Q. Lin, Y. N. Wang, X. L. Zheng, X. P. Duan, Y. Z. Yuan, J. Catal., 2013, 297, 110-118.

[41] V. H. Nguyen, H. Y. Chan, J. C. S. Wu, H. Bai, Chem. Eng. J, 2012, 179, 285-294.

[42] T. Armaroli, F. Milella, B. Notari, R. J. Willey, G. Busca, Top. Catal., 2001, 15, 63-71.

[43] E. Duprey, P. Beaunier, M. A. Springuel-Huet, F. Bozon-Verduraz, J. Fraissard, J. M. Manoli, J. M. Brégeault, J. Catal., 1997, 165, 22-32.

[44] B. Notari, Adv. Catal., 1996, 41, 253-334.

[45] E. Duprey, P. Beaunier, M. A. SpringuelHuet, E. BozonVerduraz, J. Fraissard, J. M. Manoli, J. M. Bregeault, J. Catal., 1997, 165, 22-32.

[46] A. Q. Wang, J. H. Liu, S. D. Lin, T. S. Lin, C. Y. Mou, J. Catal., 2005, 233, 186-197.

[47] A. Zecchina, S. Bordiga, G. Spoto, L. Marchese, G. Petrini, G. Leofanti, M. Padovan, J. Phys. Chem., 1992, 96, 4985-4990.

[48] G. N. Vayssilov, Catal. Rev. Sci. Eng., 1997, 39, 209-251.

[49] Z. J. Cheng, W. X. Sheng, Chin. J. Chem., 2000, 18, 42-48.

[50] S. Bordiga, A. Damin, G. Berlier, F. Bonino, G. Ricchiardi, A. Zecchina, C. Lamberti, Int. J. Mol. Sci., 2001, 2, 167-182.

[51] M. C. Capel-Sanchez, J. M. Campos-Martin, J. L. G. Fierro, M. P. de Frutos, A. P. Polo, Chem. Commun., 2000, 10, 855-856.

[52] A. Sandoval, A. Aguilar, C. Louis, A. Traverse, R. Zanella, J. Catal., 2011, 281, 40-49.

[53] T. W. Kim, M. J. Lee, J. Adv. Eng. Technol., 2010, 3, 193-198.

[54] V. H. Nguyen, J. C. S. Wu, H. Bai, Catal. Commun., 2013, 33, 57-60.

[55] V. H. Nguyen, H. Y. Chan, J. C. Wu, J. Chem. Sci, 2013, 125, 859-867.

[56] C. Murata, H. Yoshida, J. Kumagai, T. Hattori, J. Phys. Chem. B, 2003, 107, 4364-4373.

[57] C. Murata, T. Hattori, H. Yoshida, J. Catal., 2005, 231, 292-299.

[58] V. H. Nguyen, S. D. Lin, J. C. S. Wu, J. Catal., 2015, 331, 217-227.

[59] G. Mills, M. S. Gordon, H. Metiu, J. Chem. Phys., 2003, 118, 4198-4205.

[60] X. Y. Deng, B. K. Min, A. Guloy, C. M. Friend, J. Am. Chem. Soc., 2005, 127, 9267-9270.

[61] J. Guzman, S. Carrettin, A. Corma, J. Am. Chem. Soc., 2005, 127, 3286-3287.

[62] D. I. Kondarides, X. E. Verykios, J. Catal., 1996, 158, 363-377.

[63] H. Nakatsuji, Z. M. Hu, H. Nakai, K. Ikeda, Surf. Sci., 1997, 387, 328-341.

\title{
分子氧为氧化剂的 $\mathbf{A u}-\mathbf{A g} / \mathbf{T S}-1$ 光催化剂协同光催化丙烯气相环氧化
}

\author{
李乃旭 ${ }^{\mathrm{a}}$, 杨 斌, 刘 明 ${ }^{\mathrm{a}}$, 陈 勇 ${ }^{\mathrm{a}}$, 周建成 ${ }^{\mathrm{a}, \mathrm{b}, \mathrm{c},{ }^{*}}$ \\ a东南大学化学化工学院, 江苏南京 211189 \\ ${ }^{\mathrm{b}}$ 东南大学成贤学院制药与化学工程学院, 江苏南京 210088 \\ c东南大学江苏省生物药物高技术研究重点实验室, 江苏南京 211189
}

摘要: 近年来, 丙烯环氧化已引起人们广泛的兴趣; 然而, 大多数过程仍面临分离困难等问题. 此外, 丙烯转化率和环氧丙 烷 $(\mathrm{PO})$ 的选择性仍然非常低. 从环境和经济观点来看, 分子氧是丙烯选择性环氧化的理想氧化剂. 开发一种气相光催化环 氧化方法, 即在光能和多相光催化剂存在的情况下, 用于化学品生产. 因此, 本文探讨了通过光催化 $\mathrm{O}_{2}$ 选择氧化丙烯环氧 化. 传统的制备方法存在环境污染及能耗大等缺点, 而利用氧气直接进行光催化丙烯环氧化制备环氧丙烷是相当具有前 景的化学品生产途径.

本文采用水热法制备了微球状TS-1载体, 再通过浸渍还原法制备了不同 $\mathrm{Au} / \mathrm{Ag}$ 质量比的 $\mathrm{Au}-\mathrm{Ag} / \mathrm{TS}-1$ 双金属催化剂. 通 
过 $X$ 射线衍射、扫描电镜、紫外-可见吸收光谱、透射电镜、 $X$ 射线光电能谱、荧光光谱和 $N_{2}$ 吸脱附法等手段对合成的催 化剂的组成、形貌和性质进行了研究, 通过气相色谱在线分析得到光催化反应结果.

结果表明, 通过浸渍还原法可以很好的将贵金属分散到载体表面上. 对于 $\mathrm{Au}-\mathrm{Ag} / \mathrm{TS}-1$ 双金属催化剂, 当 $\mathrm{Au} / \mathrm{Ag}$ 质量比 为 $4 / 1$ 时, 反应温度为 $443 \mathrm{~K}$ 时, 环氧丙烷生成速率最大 $(68.3 \mu \mathrm{mol} /(\mathrm{g} \cdot \mathrm{h}))$, 其选择性达 $52.3 \%$. 对于 $\mathrm{Au}-\mathrm{Ag} / \mathrm{TS}-1$ 光催化剂, 双 金属负载有利于 $\mathrm{O}_{2}$ 吸附活化, 同时促进了电子的传递, 从而抑制电子空穴的复合, 有利于氧自由基的形成. 结果表明, Au, $\mathrm{Ag}$ 双金属之间存在协同催化作用, 根据实验现象提出了一种可能的反应机理.

关键词: 金; 银; 钛硅分子篮; 光催化; 丙烯环氧化; 协同作用

收稿日期: 2017-01-02. 接受日期: 2017-04-01. 出版日期: 2017-05-05.

*通讯联系人. 电话: (025)52090621; 传真: (025)52090620; 电子信箱: jczhou@seu.edu.cn

基金来源：国家自然科学基金(21576050); 江苏省自然科学基金(BK20150604).

本文的英文电子版由Elsevier出版社在ScienceDirect上出版(http://www.sciencedirect.com/science/journal/18722067). 